\title{
Coagulation System Activation for Targeting of COVID-19: Insights into Anticoagulants, Vaccine-Loaded Nanoparticles, and Hypercoagulability in COVID-19 Vaccines
}

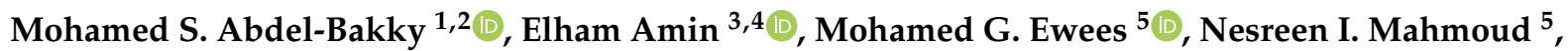 \\ Hamdoon A. Mohammed ${ }^{4,6}{ }^{D}$, Waleed M. Altowayan ${ }^{7}$ and Ahmed A. H. Abdellatif $8,9, * \mathbb{D}$
}

check for updates

Citation: Abdel-Bakky, M.S.; Amin, E.; Ewees, M.G.; Mahmoud, N.I.; Mohammed, H.A.; Altowayan, W.M.; Abdellatif, A.A.H. Coagulation System Activation for Targeting of COVID-19: Insights into Anticoagulants, Vaccine-Loaded Nanoparticles, and Hypercoagulability in COVID-19 Vaccines. Viruses 2022, 14, 228. https://doi.org/10.3390/v14020228

Academic Editors: Deborah H. Fuller, Giuseppe Camporese and Pierpaolo Di Micco

Received: 28 November 2021

Accepted: 21 January 2022

Published: 24 January 2022

Publisher's Note: MDPI stays neutral with regard to jurisdictional claims in published maps and institutional affiliations.

Copyright: (C) 2022 by the authors. Licensee MDPI, Basel, Switzerland. This article is an open access article distributed under the terms and conditions of the Creative Commons Attribution (CC BY) license (https:// creativecommons.org/licenses/by/ $4.0 /)$.
1 Department of Pharmacology and Toxicology, College of Pharmacy, Qassim University, Qassim 52471, Saudi Arabia; m.abdelbakky@qu.edu.sa

2 Department of Pharmacology and Toxicology, Faculty of Pharmacy, Al-Azhar University, Cairo 11884, Egypt

3 Department of Pharmacognosy, Faculty of Pharmacy, Beni-Suef University, Beni-Suef 62514, Egypt; El.Saleh@qu.edu.sa

4 Department of Medicinal Chemistry and Pharmacognosy, College of Pharmacy, Qassim University, Qassim 52471, Saudi Arabia; ham.mohammed@qu.edu.sa

5 Department of Pharmacology and Toxicology, Faculty of Pharmacy, Nahda University, Beni-Suef 11787, Egypt; mohamed_pharma86@yahoo.com (M.G.E.); nesreen.mahmoud@nub.edu.eg (N.I.M.)

6 Department of Pharmacognosy, Faculty of Pharmacy, Al-Azhar University, Cairo 11884, Egypt

7 Department of Pharmacy Practice, College of Pharmacy, Qassim University, Qassim 52471, Saudi Arabia; w.altowayan@qu.edu.sa

8 Department of Pharmaceutics, College of Pharmacy, Qassim University, Qasssim 52471, Saudi Arabia

9 Department of Pharmaceutics and Pharmaceutical Technology, Faculty of Pharmacy, Al-Azhar University, Assiut 71524, Egypt

* Correspondence: a.abdellatif@qu.edu.sa

\begin{abstract}
The severe acute respiratory syndrome coronavirus 2 (SARS-CoV-2), also known as COVID19 , is currently developing into a rapidly disseminating and an overwhelming worldwide pandemic. In severe COVID-19 cases, hypercoagulability and inflammation are two crucial complications responsible for poor prognosis and mortality. In addition, coagulation system activation and inflammation overlap and produce life-threatening complications, including coagulopathy and cytokine storm, which are associated with overproduction of cytokines and activation of the immune system; they might be a lead cause of organ damage. However, patients with severe COVID-19 who received anticoagulant therapy had lower mortality, especially with elevated D-dimer or fibrin degradation products (FDP). In this regard, the discovery of natural products with anticoagulant potential may help mitigate the numerous side effects of the available synthetic drugs. This review sheds light on blood coagulation and its impact on the complication associated with COVID-19. Furthermore, the sources of natural anticoagulants, the role of nanoparticle formulation in this outbreak, and the prevalence of thrombosis with thrombocytopenia syndrome (TTS) after COVID-19 vaccines are also reviewed. These combined data provide many research ideas related to the possibility of using these anticoagulant agents as a treatment to relieve acute symptoms of COVID-19 infection.
\end{abstract}

Keywords: hypercoagulability; COVID-19; natural anticoagulants; nanoparticles; targeting; COVID-19 vaccines

\section{Introduction}

The most common symptoms observed in COVID-19 patients are fever, fatigue, and cough, which are mostly associated with less frequent symptoms such as headache, dyspnea, skin rashes, sore throat, diarrhea, anosmia, and nausea [1]. Around 80\% of COVID-19 patients do not need hospitalization [2]. Owing to COVID-19 infection, severe acute respiratory syndrome coronavirus (SARS-CoV) binds to angiotensin-converting enzyme 2 receptor (ACE2), which is widely expressed all over the body, such as arterial smooth muscle cells in 
many organs, such as lung type II alveolar cells, enterocytes of the small intestine, arterial and venous endothelial cells, the neural cortex, and the brainstem [3,4]. Interestingly, several systems, such as coagulation [5,6] and immune systems [6], are activated after COVID-19 infection. However, the correlation between COVID-19 infection and activation of the coagulation system still requires elucidation. RNA virus infections, such as COVID19, flavivirus (Dengue fever), filovirus (Ebola), and arenavirus (Lassa) [7], are reported to activate the coagulation system. Therefore, previous data might help understand the correlation between hypercoagulability and COVID-19.

Thrombocytopenia and increased blood levels of D-dimer have been reported in $36.2 \%$ and $46.4 \%$ of the total reported patients, respectively, and become even higher in severe cases [1]. Although earlier research supported the idea that disseminated intravascular coagulation (DIC) was connected to the increased mortality in COVID-19 pneumonia [8], DIC is generally uncommon in COVID-19 patients [9]. Moreover, the percentage of complicated COVID-19 cases by DIC has been found to be $0.6 \%$ for survivors and $71.4 \%$ for non-survivors [10]. In addition, prognosis outcome is directly correlated with prothrombin time (PT) and the levels of fibrin degradation products (FDP) in COVID-19 infected patients [10]. Moreover, decreased platelet counts (thrombocytopenia) have also been associated with severe COVID-19 [11]. Activation and elevation of the immune system, Toll-like receptors, Willebrand factor, and endothelial dysfunction are all involved in the pathogenesis of viral infection [12-15]. Platelets' interaction, white blood cells (WBCs), and endothelial cells play a pivotal role in the activation of the coagulation system in different viral infections [16,17]. Nanotechnology is considered a viable medicine delivery method. A variety of biological applications in vitro and in vivo have been shown to be suitable for their bioactive qualities [2]. The intense interest in nanoparticles and their derivatives has increased therapy options. Applications of nanotechnology in medicine, biomedical research, and biotechnology include cancer cell-targeted therapy and other biomedical treatments [18]. Furthermore, nanotechnology can help prevent COVID-19 by employing vaccine-loaded nanoparticles [19]. However, the nanoparticles have effect on the blood coagulation system have received little consideration. Nanoparticles that interact with the blood coagulation system can have both positive and negative effects on the host [20]. The relationship between COVID-19 and hypercoagulability, specific hypercoagulability markers, anticoagulant therapeutic approaches, natural anticoagulants, and nanoparticle formulations of COVID-19 drugs such as anticoagulants are reviewed in this article.

\subsection{Coagulation System Activation in Different Diseases}

Several investigations have focused on the proinflammatory role of the coagulation system that leads to non-hematological pathological conditions (Figure 1). For example, Lorenzano et al., (2019) reported that there is a strong correlation between the deposition of different coagulation factors in the CNS and neuro-inflammation and neurodegeneration [21]. In addition, Davalos et al., (2019) reported that fibrinogen passes the blood-brain barrier (BBB) when it is disrupted and consequently spreads and converts into fibrin in the CNS; this triggers an inflammatory response and immune activation [22]. Moreover, this cytotoxicity has been observed in autoimmune encephalomyelitis and multiple sclerosis (MS) pathogenesis [23].

Interestingly, cancer patients are at high risk of endothelial injury and an imbalance between pro- and anti-thrombotic factors, leading to a hypercoaguable state. This may be caused by patient-specific, chemotherapy-related, and tumor-specific factors resulting in the deposition of intravascular fibrin with depletion of blood clotting factors and development of thrombocytopenia [24]. Tissue factor (TF) is also overexpressed in different types of tumors such as colorectal, gastric, pancreatic, and lung cancer [25]. It has been demonstrated by Abdel-Bakky et al., (2011) that TF mediates liver toxicity in the monocrotaline/lipopolysaccharide mice model [26]. Similarly, TF blocking by deoxyoligonuceotides antisense is successfully prevented by thioacetamide [27], CCL4-induced liver injury in mice [28], and monocrotaline/lipopolysaccharide-induced renal toxicity in mice [29]. 


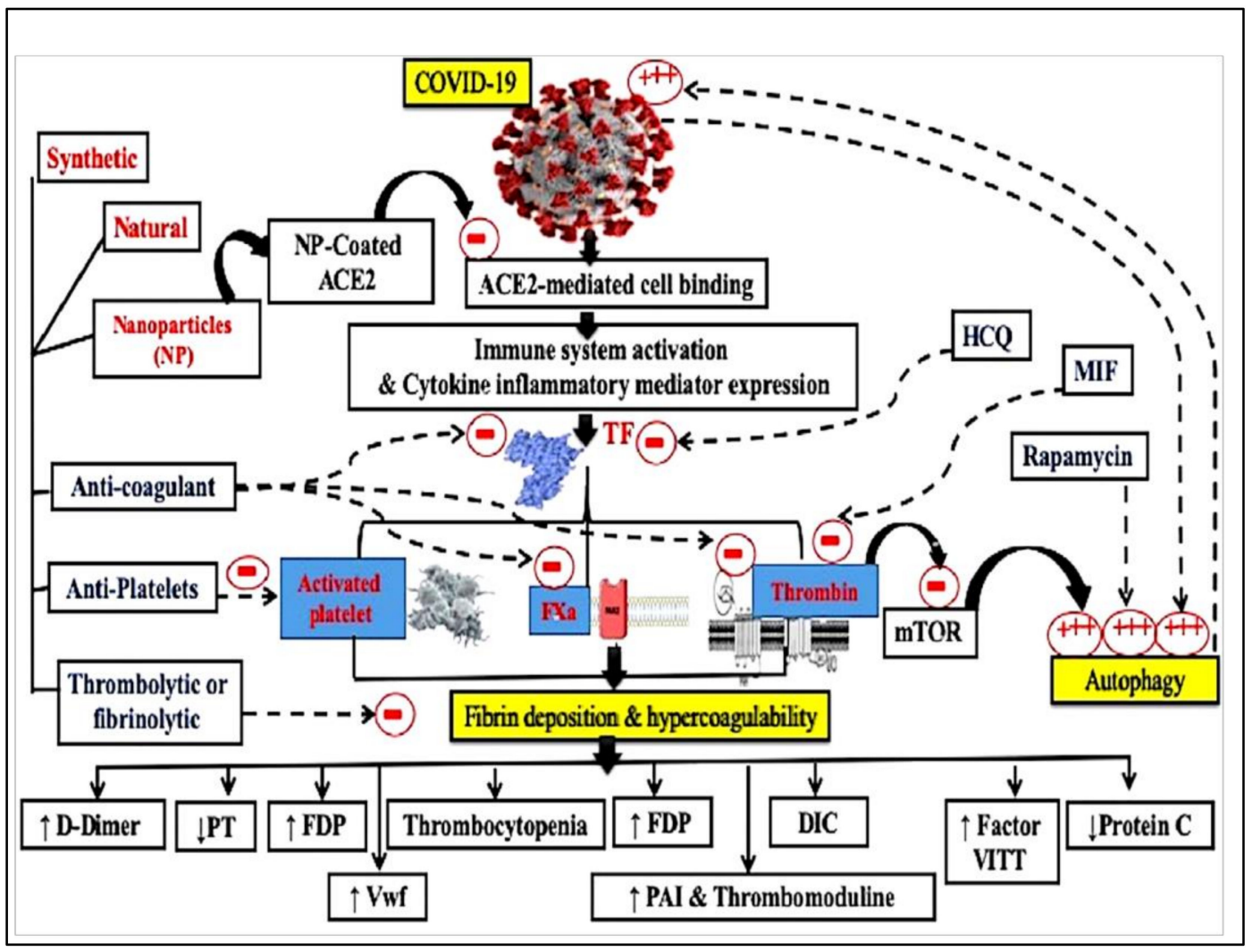

Figure 1. Schematic diagram representing the different coagulation system mechanisms and possible types of coating nanoparticles for targeting ang I and II receptors. DIC, disseminated intravascular coagulation; Fxa, activated factor x; PT, prothrombin time; TF, tissue factor; Hydroxychloroquine- $\mathrm{HCQ}$; Macrophage migration inhibitory factor-MIF; Fibrin degradation products-FDP; Von Willebrand factor-Vwf; Mammalian target of rapamycin-mTOR; plasminogen activator inhibitor-PAI.

Therefore, targeting coagulation systems is an important potential therapeutic tool for a wide range of diseases. The antiplatelet drug clopidogrel and/or the thrombin inhibitor dabigatran can be used as a prophylactic approach against liver fibrosis [30]. Ewees et al., (2018) suggested that the use of the anticoagulant, rivaroxaban, factor Xa (FXa) inhibitor could be a useful protection against cisplatin-induced acute tubular necrosis [31]. Dabigatran, the direct thrombin inhibitor, has also shown efficacy in a breast cancer murine model [32]. Side by side, FXa inhibitors are used in clinical trials to decrease coagulation cascade activation and to increase microvascular circulation in sickle cell disease (SCD) [33].

Moreover, the "Middle East respiratory syndrome" (MERS-CoV) was initially identified in Saudi Arabia in 2012 and was associated with thrombotic complications and hematologic manifestations [5]. Thrombocytopenia was reported in $36 \%$ of 47 laboratoryconfirmed MERS-CoV cases in Saudi Arabia [34]. Interestingly, clinical and post-mortem examination reports of COVID-19 patients from China and the United States have revealed increased clotting and scattered intravascular coagulation with small vessel thrombosis and pulmonary infarction $[35,36]$. Furthermore, low platelet levels, elevated D-dimer, and prolonged PT relate to worse results in patients with COVID-19 [10].

Viral infection triggers an inflammatory immune response, causing the activation of the coagulation system [5]. The excessive release of coagulation factors is controlled by negative feedback and physiological anticoagulants such as TF inhibitor, anti-thrombin, and the protein $C$ system. Increased consumption of physiological anticoagulants disrupts procoagulant and anticoagulant homeostatic mechanisms, resulting in D-dimer elevation and the development of micro thrombosis with scattered intravascular coagulation in severe COVID-19 [37,38]. Therefore, we suggest that it is a good practice to use anticoagulant 
therapy carefully in calculated and controlled doses to decrease the risk of thrombosis and improve the clinical management in COVID-19 patients.

\subsection{Hypercoagulability and Viral Infections}

Hypercoagulability and vascular injury are stimulated by inflammation and hysterical viral replication [39]. In the Ebola viral infection, $30 \%$ of the patients showed hemorrhagic symptoms [40]. Wang et al., (2011) reported that patients with influenza A (H1N1) have low lymphocytes and high D-dimer levels. The significantly elevated D-dimer indicates the probability of the formation of a pulmonary microthrombus. Thus, they recommended that it may be necessary to consider anticoagulant therapy [41]. In addition, Borges et al., (2014) stated that D-dimer levels increased in $\mathrm{HIV}^{+}$men and women and hepatitis B/C co-infected individuals [42]. Host inflammatory responses and/or antigen-antibody complexes of the virus can activate platelets, which are then cleared from the circulation by the reticuloendothelial system [43]. Platelets can be reduced by an interaction between megakaryocytes and viruses [44].

However, severe acute respiratory syndrome-COV-1 (SARS-CoV-1) has been associated with a low prevalence of bleeding. It caused pulmonary embolism, induced thrombocytosis, thrombocytopenia, long PT, and activated partial thromboplastin time (aPTT) [45,46]. It is noteworthy that COVID-19 may have a similar complication pattern to SARS-CoV-1. Interestingly, thrombocytopenia, which results from hypercoagulopathy in sepsis, has a relatively low prevalence in SARS-CoV-1 [47] and COVID-19 [1].

Thrombocytopenia in COVID-19 could be explained by continuous migration and consequent consumption of the platelets from the blood, owing to continuous inflammatory status [48]. The uncontrolled increase in the proinflammatory cytokines IL-6 and IL-1, which induce "cytokine storm" and can stimulate megakaryocyte proliferation, probably causing thrombocytosis.

The invasion of coronavirus through the airway causes tissue injury and elicits innate immune responses wherein the viral particles stimulate the activation of resident alveolar macrophages and complement cascade through the lectin pathway. Upon complement activation, the membrane attack complex can directly cause endothelial cell damage [49]. Furthermore, TF becomes exposed to external surfaces and comes into contact with coagulation factor VII, thereby activating the extrinsic coagulation pathway. Leukocyte infiltration and TF expression in inflammatory monocytes further worsen thrombotic complications. The generation of proinflammatory cytokines and vascular inflammation is mediated by several pattern recognition receptors, known as toll-like receptors (TLRs) and nod-like receptors (NLRs). In addition, activation of TLRs mediated by oxidized phospholipids and damaged cells' hypoxic conditions caused by viral infection leads to monocyte infiltration and activates the production of TNF- $\alpha$, IL6, IL-8, and interferon-c (INF-c), resulting in massive vascular endothelial and alveolar epithelial cell damage [50]. TLR3 can also cause hypercoagulation by activating TF expression [51]. Thus, coagulation system activation could be a risk factor for adverse outcomes of viral infection and, consequently, COVID-19 and should be taken into account in clinical practice.

\subsection{Hypercoagulability Markers in COVID-19}

There is a correlation between activation of the coagulation system and poor prognostic cases of severe infection of COVID-19 [10]. Currently, D-dimer, FDP, and PT are among the most important hypercoagulability markers in the COVID-19 pandemic. D-dimer is elevated in more than $45 \%$ of patients and is considered an independent risk factor for mortality in COVID-19 [38,52]. Patients with D-dimer level greater than $1000 \mathrm{ng} / \mathrm{mL}$ are at risk of death 20-fold more than patients with lower levels [38]. A retrospective study on 1099 patients, admitted to 552 hospitals all over China, showed that D-dimer is strongly elevated in patients with severe COVID-19 (59.6\% of the patients) compared to less severe cases (43.2\% of the patients) [1]. 
Platelets are another hypercoagulability parameter that was found to have decreased in the blood (thrombocytopenia) of severe COVID-19 cases (57.7\% of the patients) in a retrospective study that used 1338 patients in many hospitals all over China [1]. However, a retrospective analysis in Tongji hospital showed that there was a high platelet count in patients with severe pneumonia owing to COVID-19 compared with non-COVID-19 ones [53].

A study was performed on a group of 22 patients suffering from acute respiratory failure and admitted to the ICU in the Hospital of Padova University after COVID-19 infection. The result showed that patients had significantly increased plasma levels of fibrinogen compared to healthy control patients [54]. A small thrombus containing fibrin/platelet was found in the pulmonary parenchyma and microcirculation after the development of ARDS in COVID-19 infected patients [55].

Furthermore, von Willebrand factor (VWF) and factor VIII activities are significantly increased in COVID-19 patients [56]. There was an increase in factor VIII and VWF in a study performed by Panigada et al., (2020) on 24 COVID-19 patients admitted to ICU [57]. In some studies, ARDS patients with associated disease severity, multiple organ failure, and mortality showed increased levels of plasminogen activator inhibitor-1 (PAI-1) and soluble thrombomodulin and decreased level of protein C [58-62]. In addition, COVID-19 patients developed ARDS with an increased level of TF in alveoli and plasma compared to pulmonary edema patients without COVID-19 [63]. High mortality rates owing to thrombotic complications are considered an important consequence of COVID-19 infection; therefore, approaches to inhibit thrombosis in COVID-19 patients are very important. Antithrombotic drugs such as heparin, fibrinolytics, dipyridamole, FXII inhibitors, and nafamostat have pleiotropic anti-inflammatory or antiviral effects [64].

Several capillary and vascular diseases, for example, hypercoagulability, microangiopathy, and venous/arterial thromboembolic crises are commonly associated with the natural COVID-19 infection, especially in moderate to severe cases [65]. Meanwhile, adenoviral vector-based vaccines can bind platelets and induce their destruction in the reticuloendothelial system. In addition, liposomal mRNA-based vaccines may activate the coagulation factors and provide a pro-thrombotic phenotype to endothelial cells and platelets [66]. Due to an imbalance in clinical trials, hypercoagulability is a risk management plan (RMP) and an important potential risk associated with the administration of the recently approved COVID-19 Vaccine Janssen, another adenovirus vaccine. The high level of systemic inflammatory response (SIR) within severe COVID-19 cases is a potential assumed mechanism that is related to the hypercoagulable statistics among patients [67]. Moreover, there is an association between adenoviral vector or mRNA-based COVID-19 vaccines and thrombotic events, resembling antiphospholipid syndrome (APS), which has appeared in few cases of thrombocytopenia after vaccination. This association appeared through the trigger of type I interferon response, which is associated with the generation of antiphospholipid antibodies (aPLs). aPLs may directly cause the activation of immune response and participation of innate immune cells, cytokines, and complement cascade. Therefore, aPLs that are linked with the risk of APS might represent a risk factor for thrombotic events following COVID-19 vaccination [68]. The major issue of SARS-CoV-2 infection without prior vaccines and immunity is the pathophysiologic responses associated with acute infection-hypercoagulability and thrombo-inflammation-which might drive the disease process and ongoing worldwide crises [69].

\subsection{Fibrinolysis in COVID-19 Patients}

Plasmin, a serine protease, is the main component in the fibrinolytic system. It results from the activation of plasminogen into plasmin [70]. Fibrinolysis is activated by tissue type plasminogen activator (tPA) and urokinase-type plasminogen activator (uPA). They bind to their specific receptors on cell surfaces. In order to prevent the over activation of fibrinolytic process, serine protease inhibitors (serpins) regulate fibrinolysis at various activation sites. Those inhibitors include activated protein C inhibitor (APC) inhibitor 
(PAI-3), plasminogen activator inhibitor 1 (PAI-1), plasminogen activator inhibitor 2 (PAI-2), defensin, and protease nexin 1, which inhibit the conversion of plasminogen to plasmin [71]. Suppression of fibrinolysis is exhibited frequently in cases of acute lung injury (ALI) [72,73]. Inhibition of fibrinolysis is considered an important provoking factor causing thrombotic complications that increase the severity of COVID-19. In sepsis, it is associated with disease progression, cell injury, and increased mortality rate [74,75]. Elevated thrombin activatable fibrinolysis inhibitor (TAFI) and PAI-1 were found to be a leading cause of hypofibrinolysis in COVID-19 patients [14]. In the acute phase of COVID-19 infection, influx of the coagulation factors and fibrinogen containing inflammatory fluids leads to formation of hyaline membrane and fibrin accumulation. Furthermore, increased inflammatory cytokines, such as IL-1, IL-6, and IL-17A, increase PAI-1 and inhibit uPA expressions [76,77]. A hypofibrinolysis then occurs, leading to not only increased fibrin accumulation and hyaline membrane formation but also a state of microvascular thrombosis. After prolonged COVID-19 infection, epithelial cells pass through an epithelial-mesenchymal transition [78] and consequently lead to fibrosis [79]. Therefore, it is worth noting that the degree of fibrinolytic state depends accordingly upon the severity of COVID-19.

\subsection{Therapeutic Approaches for Hypercoagulability in COVID-19}

Most of the complications of COVID-19 are DIC and hyperactivity of the host immune response [80]. Increased blood coagulation markers in patients with ARDS and sepsis are mostly associated with bad prognoses and poor outcomes. Therefore, anticoagulants such as heparin have been used clinically to target the coagulation system [81]. A recent retrospective study revealed the prophylactic or therapeutic benefits of heparin in patients with severe COVID-19 infection. Heparin may improve the situation through its anticoagulant and anti-inflammatory effects [37]. The International Society on Thrombosis and Haemostasis (ISTH) and the American College of Cardiology (ACC) have recently recommended a prophylactic calculated dose of heparin with low-molecular-weight (LMWH) or unfractionated heparin in all severe cases of COVID-19 patients [82,83]. Heparin is suggested to be used at a dose of $50 \mathrm{UI} / \mathrm{Kg}$ and in patients with bleeding or with thrombocytopenia [84].

Careful selection of appropriate anticoagulant drug(s) and dosage in addition to close observation of patients are very important, especially in patients with chronic diseases such as diabetes, hypertension, and liver disease. Therefore, special care must be taken with regards to patients with inherited related coagulation diseases such as von Willebrand hemostasis and hemophilia A or B.

\subsection{Natural Products as Anticoagulants}

All characteristics of the coagulation cascade, primary hemostasis, coagulation, and fibrinolysis can be affected during viral infections; therefore, thrombosis and DIC may occur. During severe viral infections, nothing can be used except supportive treatment [85]. After vascular damage, the integrity of the high pressured closed circulatory system is preserved by the hemostatic system. Normally, thrombi formation is controlled by a regulatory system; however, under pathological conditions or a shift in the hemostatic balance toward the procoagulant side, thrombi formation is initiated [86]. Hemostasis disorders are a serious manifestation in COVID-19 patients. Thrombotic complications are among the most important causes of death in patients with severe COVID-19 infection. Many research programs are directed toward finding new effective and safe antithrombotic agents. In this regard, natural products present a generous source for promising candidates because they are cheaper and less toxic than synthetic drugs. Accordingly, they can offer important complementary drugs for recovering from hemostasis disorders in COVID-19 patients. Table 1 shows different natural sources, either in the form of extracts or isolated pure compounds, that have been reported to possess antithrombosis activity. Chen et al., (2015) reviewed natural products on the basis of their antithrombosis activity. They classified the drugs into antiplatelet aggregation, anticoagulant, and fibrinolytic acting drugs [87]. Anticoagulant drugs were further classified into TF inhibitors and inhibitors of the coagulation 
pathway. Likewise, antiplatelet drugs were subdivided into four main subclasses: drugs that act as inhibitors of platelet membrane receptors, drugs that impact on the nucleotide system, inhibitors of platelet granules secretion, and drugs that impact on the arachidonic acid system (Table 1). A wide variety of natural products, primarily from plants, were proved to exhibit a significant fibrinolytic activity, e.g., gingko, ginger, raspberries, garlic, onion, fermented soybeans, Ananas comosus, Fagonia arabica, Spirodela polyrhiza, Flammulina velutipes, Lagenaria siceraria, Bacopa monnieri, Clausena suffruticosa, Leea indica, Leucas aspera, Pinus densiflora, Lonicera japonica, Sargassum fulvellum, Pueraria lobata, Trichosanthes kirilowii, Lonicera japonica, and Desmodium styracifolium [88].

Nowadays, marine organisms receive considerable interest as a renewable source for drugs. During the last few years, several antithrombotic drugs have been reported from marine sources. Marine polysaccharides represent an important class of marine-derived antithrombotic agents. Kuznetsova et al., (2021) reviewed the potency of seaweed sulfated polysaccharides for correcting hemostasis disorders in COVID-19 [89]. Moreover, other molecules from different chemical classes, such as peptides, polyketides, steroids, terpenes, alkaloids, and polyphenols, have proven antithrombosis efficacy in in vitro and in vivo assays. Some secondary metabolites such as terpenes (dichotomanol, dolastane diterpene, and pachydictyol), protein (YAP), and polyphenol (phloroglucinol) exhibited anticoagulant and antiplatelet activities [90].

Therefore, it is clear that natural products, whether from terrestrial or marine sources, are a diverse source of anti-thrombotic agents. In this context and on the basis of the diversified mechanisms of action of natural products, these agents could be considered as a complement to the currently used anti-thrombotic drugs. Hence, it can be one of the recommended medications to reduce deaths from COVID-19 infection. Nevertheless, to date, no research findings regarding the investigation of the use of natural anticoagulants as supportive therapy for COVID-19 infection have been published.

Table 1. Natural sources (for extracts or pure compounds) used as antithrombosis and their mechanisms of action.

\begin{tabular}{|c|c|c|c|c|}
\hline & chanism of Action & Natural Source & Active Constituents & References \\
\hline \multirow{13}{*}{ 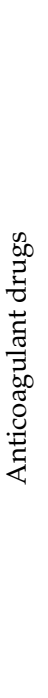 } & \multirow{4}{*}{ 1-TF inhibitors } & Chaenomeles sinensis & $\begin{array}{l}\text { Hovertrichoside, } \\
\text { luteolin-7-O- } \beta \text {-D-glucuronide, hyperin, } \\
\text { avicularin and quercetin }\end{array}$ & [91] \\
\hline & & Ligustici chuanxiong & Ligustrazine & [87] \\
\hline & & Eriobotrya japonica Lindley & Sesquiterpene glycoside & {$[92]$} \\
\hline & & Beans and grain & $\alpha$-Zearalanol & [87] \\
\hline & \multirow{9}{*}{$\begin{array}{l}\text { 2-Inhibitors of the intrinsic } \\
\text { and extrinsic coagulation } \\
\text { pathways }\end{array}$} & The green algae Monostroma arcticum & Polysaccharide & [87] \\
\hline & & Polygala fallax Hesml. & Saponins & [87] \\
\hline & & Rhododendron brachycarpum & Hyperoside, & [93] \\
\hline & & Umbilicaria esculenta & Polysaccharide & [94] \\
\hline & & Withania somnifera & Withaferin A & [95] \\
\hline & & Scutellaria baicalensis Georgi & Wogonin and wogonoside & [96] \\
\hline & & Erigeron canadensis L. & Polyphenolic-polysaccharide preparation & [97] \\
\hline & & Codium vermilara & Polysaccharide & [98] \\
\hline & & Crassocephalum crepidioides & Crude extract & [99] \\
\hline
\end{tabular}


Table 1. Cont.

\begin{tabular}{|c|c|c|c|c|}
\hline & Mechanism of Action & Natural Source & Active Constituents & References \\
\hline \multirow{41}{*}{ 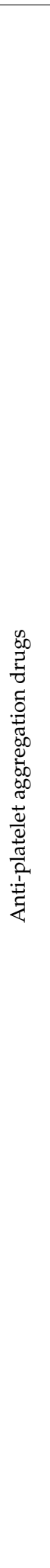 } & \multirow{4}{*}{$\begin{array}{l}\text { 1-Acting by variable } \\
\text { mechanisms }\end{array}$} & Andrographis paniculata & Andrographolide & [100] \\
\hline & & Bupleurumfalcatum & Bupleurumin & [101] \\
\hline & & Salvia milthorriza Bunge & Tanshinone IIA & [102] \\
\hline & & Abies webbiana, parsley, Nigella sativa & Crude extract & [103-105] \\
\hline & \multirow{14}{*}{$\begin{array}{l}\text { 2-Inhibitors of platelet } \\
\text { membrane receptors }\end{array}$} & Spatholobus suberectus, garlic & Crude extract & {$[106,107]$} \\
\hline & & Rabdosia japonica var. glaucocalyx & Glaucocalyxin A & [108] \\
\hline & & Salvia miltiorrhiza & Salvianolic acid B & [109] \\
\hline & & Garcinia nervosa var. pubescens King & Flavonoids & [110] \\
\hline & & Erylus formosus & Eryloside F & [111] \\
\hline & & Piper longum & Piperlongumine & [112] \\
\hline & & Licania pittieri & Pomolic acid & [113] \\
\hline & & Polygonum multiflorum & Tetrahydroxystilbene glucoside & [114] \\
\hline & & Agkistrodon acutus Venom & Tripeptide & [115] \\
\hline & & Cruciferous vegetables & Indole-3-carbinol & [116] \\
\hline & & Goniothalamus species & Essential oils & [117] \\
\hline & & Ligusticam wallichii Franch & Tetramethyl pyrazine & [118] \\
\hline & & Agrimonia pilosa, Toona sinensis & Crude extract & [87] \\
\hline & & Rhus verniciflua Stokes & Isomaltol and pentagalloyl glucose & [119] \\
\hline & \multirow{3}{*}{$\begin{array}{l}\text { 3-Impacting on nucleotide } \\
\text { system. }\end{array}$} & Cordyceps militaris & Cordycepin & [120] \\
\hline & & Ginkgo biloba & Ginkgolide C, quercetin & [121] \\
\hline & & Oligoporus tephroleucus & Oligoporin A & [122] \\
\hline & \multirow{6}{*}{$\begin{array}{l}\text { 4-Inhibitors of platelet } \\
\text { granules secretion. }\end{array}$} & Saffron & Crocetin & [123] \\
\hline & & Black soybean & Crude extract & [124] \\
\hline & & Magnolia bark & Magnolol & [125] \\
\hline & & Solanum lycopersicum & Guanosine & [126] \\
\hline & & Ligustici Chuanxiong & Ligustrazine ferulate, & [87] \\
\hline & & Rhizoma Curcumae & Curdione & [127] \\
\hline & \multirow{14}{*}{$\begin{array}{l}\text { 5-Impacting on } \\
\text { arachidonic acid system }\end{array}$} & Green tea leaves & Epigallocatechin-3-gallate & [128] \\
\hline & & Zizyphus jujube & Jujuboside B & [129] \\
\hline & & Sorghum vinegar & Alditol and monosaccharide & [130] \\
\hline & & Magnolia obovate & Diacetylated obovatol & [131] \\
\hline & & Artemisia princeps Pampanini & Crude extract, eupatilin, and jaceosidin & [132] \\
\hline & & Grape fruits and oranges & Hesperetin & [133] \\
\hline & & Betel leaf & Hydroxychavicol & [134] \\
\hline & & Stephaniae tetrandrae & Tetrandrine and fangchinoline & [135] \\
\hline & & Uncaria sinensis (Oliv.) Havil. & Isorhynchophylline & [87] \\
\hline & & Caesalpinia sappan $\mathrm{L}$. & Ethyl acetate extract & [87] \\
\hline & & Cornus officinalis Sieb. et Zucc & Morroniside & [87] \\
\hline & & $\begin{array}{l}\text { Pleurothyrium cinereum, Ocotea } \\
\text { macrophylla and Nectandra amazonum }\end{array}$ & Neolignans & [136] \\
\hline & & Zingiber mioga Roscoe & Crude extracts & [137] \\
\hline & & White ginseng & Ginsenoside Rk1 & [138] \\
\hline
\end{tabular}




\subsection{Nanotechnology for Future Treatment of COVID-19}

Nanomaterials are effective tools in the field of medicine because they can target highly specific cells and avoid the side effects of medical drug use. In particular, nanoparticles (NPs) can bind with ligands to target cell surfaces. NPs can be conjugated with ligands for active targeting; these ligands could be peptides, antibodies, or hormones [139,140]. This kind of conjugation could be beneficial for destroying viruses such as COVID-19. Through the management of size; surface features; and the material used as smart systems by encasing, enclosing, and coating the drugs and imaging agents, nanoparticles can be used in drug delivery. The potential uses of anticoagulation in COVID-19 could be of interest when conjugated with NPs. For example, heparin as an anticoagulant can be conjugated to NPs as an antiviral agent against COVID-19 (Figure 2) [141].

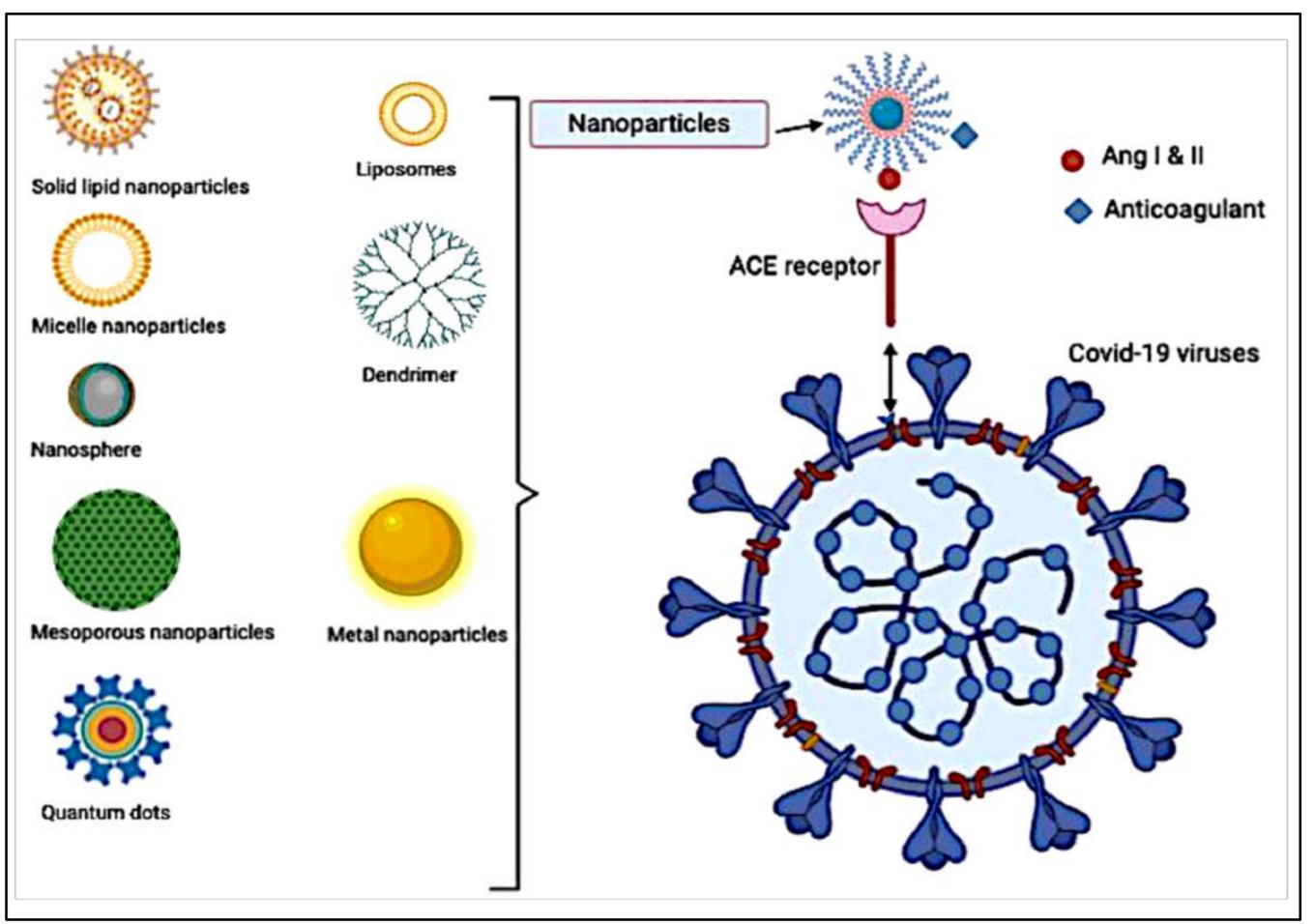

Figure 2. Schematic diagram representing the different formulated nanoparticles coated with anticoagulant for targeting ang I and II receptors.

To date, the most promising approach to treating thrombosis using nanomedicine has been to deliver antithrombotic drugs to thrombus sites by targeting one or more proteins involved in coagulation (for example, fibrin, thrombin, or hydrogen peroxide $\left(\mathrm{H}_{2} \mathrm{O}_{2}\right)$ ) to the thrombus sites. A different approach, which has been documented previously, involves the targeting of cells such as active platelets involved in the coagulation process, with cell-binding ligands. Researchers were able to reduce the formation of $\mathrm{H}_{2} \mathrm{O}_{2}$, using an $\mathrm{H}_{2} \mathrm{O}_{2}$-responsive boronate antioxidant polymer (BAP) bonded to the fibrin-targeting lipopeptides. In rat models, Kang et al., 2017 demonstrated that nanoparticles could carry tirofiban to the thrombus site, reducing $\mathrm{H}_{2} \mathrm{O}_{2}$ production and hence TNF- $\alpha$ and soluble CD40 [142]. Both functionalized iron oxide nanoparticle micelles and bare nanoparticles were used to detect thrombus locations using magnetic particle imaging [143]. Superparamagnetic iron oxide nanoparticles coated with fucoidan, a polysaccharide with a high affinity for activated platelets, have been demonstrated to connect to P-selectin and aid the detection of thrombus formation in vivo, according to researchers [144]. Additionally, liposome nanoparticles containing cyclic Arg-Gly-Asp (RGD) on their surfaces are effective at targeting the activated platelet receptor integrin GPIIb-IIIa [145]. Park et al., (2006) produced an amphiphilic combination of heparin and deoxycholic acid that encapsulated doxorubicin 
in a two-step method for SCC (squamous cell carcinoma). Therefore, nanoparticles were examined for cytotoxicity, antitumor activity, and toxicity. The conjugate has high loading and release efficiency, promoting antitumor activity [146]. The heparin/DOX/DEVD-SDOX complex was formed first by Khaliq et al., (2006). The composite was then stabilized using Pluronic F-68. When delivered to the tumor site, DOX (doxorubicin) was exposed to the tumor cells, prompting apoptosis and recurrent activation of caspase-3. Caspases are proteases that control cell death and inflammation-they cause apoptosis, which is triggered in nanoformulations. This study used SCC-7 murine squamous cell carcinoma cells [147].

Additionally, these systems can deliver anticoagulant drugs to specific tissues and ensure controlled-release therapy [148]. The anticoagulant drugs can be taken via inhalation, absorption throughout the skin, or injection. Smart nanocarriers comprised organics (polymeric micelles, liposomes, and hydrogels), which can enclose anticoagulant drugs inside, and inorganics (quantum dots, gold, and silica nanoparticles), which can carry the anticoagulant on their surfaces [149]. Lembo et al. [150] developed heparin nanoassemblies based on the self-association of O-palmitoyl-heparin and a-cyclodextrin in water for antiviral activity against herpes simplex viruses, human papillomavirus, and respiratory syncytial virus. Joshi et al. [151] conjugated chloroquine as an antiviral drug with thiol-functionalized gold nanoparticles, and the chloroquine-conjugated gold nanoparticles interacted well with bovine serum albumen and showed antiviral activity. Hsu et al. [152] used berberine, a natural isoquinoline alkaloid with antiviral activity, and then formulated it as novel berberine nanoparticles comprising heparin and shelled with linear polyethyleneimine.

The SARS-CoV-2 virus that produces COVID-19 disease enters the cells by targeting receptors of angiotensin-converting enzyme 2 (ACE2). Because the virus has ACE2 receptors, the NPs can also carry anticoagulants and conjugate with ACE2 ligands to bind to receptors of the virus cell. Figueroa et al. [153] developed NP-coated angiotensin-converting enzyme on their surface using angiotensin for targeting viruses. The presence of the receptor on the surface of the viruses confirmed NP uptake via endocytosis. The results proved that the design of virus-mimetic cell interactive NPs is a precious strategy for improving NP specificity for therapeutic and diagnostic applications. Itani et al., (2020) suggested the development of theranostic NPs for the professional and selective delivery of beneficial moieties (that is, drugs such as anticoagulants, vaccines, siRNA, peptides) to actively target sites of infection and help in the fight against COVID-19 [154]. They suggested this kind of NPs because intranasal delivery was the favorite administration route against viral pulmonary diseases. The theranostic NPs can be divided into three broad categories: (1) the organic category such as liposomes, polymeric nanoparticles, and dendrimer; (2) inorganic category, such as gold, silver, quantum dots, and iron nanoparticles; and (3) virus-like or self-assembling protein nanoparticles [148]. Therefore, the formulation of the currently used anti COVID-19 drugs that have anti-hypercoagulability in a nanoparticle form appears to be a promising strategy in the future.

Unusual thrombosis and thrombocytopenia have been identified as uncommon side effects linked with the ChAdOx1 nCov-19 (AstraZeneca) COVID-19 vaccination. The underlying causes of this uncommon disease are unknown; however, a clinical similarity to heparin-induced thrombocytopenia (HIT) has been noticed. Eichinger and colleagues examined individuals who acquired a coagulation condition resembling HIT following immunization with $\mathrm{ChAdOx} 1 \mathrm{nCov}-19$, even though they did not receive heparin prior to symptom onset. Plasma samples from patients indicated the presence of an antibody consistent with an autoimmune form of HIT, in which platelets become abnormally activated in the absence of heparin. The authors proposed a diagnostic and therapeutic strategy for treatment on the basis of test and clinical data $[155,156]$. Furthermore, current research shows that $20-30 \%$ of patients at high risk of COVID-19 mortality develop blood clotting, resulting in stroke and sudden death. Identifying the degree of blood clotting can help clinicians choose the best blood thinners to avoid life-threatening complications. Rapid detection of clotting-related proteins in COVID-19 plasma could save countless lives. Patients 
at high risk of death from COVID-19 infections, including blood clots, are being identified using nanotechnology. With improved mass spectrometry-based proteomics methods, nanomedicine can discover critical protein patterns that are involved in the occurrence and course of this disease. The combination of these sophisticated techniques may help us better understand clotting and develop new diagnostics and therapies for COVID-19 [157].

\subsection{Nanoparticle-Loaded Anticoagulants}

Several anticoagulant-based nanoformulations for delivery systems have been investigated to increase their therapeutic efficacy while also decreasing their toxicity when administered through diverse routes. Whatever the drug delivery system (DDS) is used, the evaluation of anticoagulant performance is essential for the creation of a DDS that is appropriate for patients. In both scientific research and clinical practice, it is critical to have a thorough grasp of the many anticoagulant tests available, as well as their main uses and limits. This is partly owing to the use of nanoscale formulations in anticoagulant treatment. In recent years, the limits to the use of anticoagulants have been lessened [158].

Table 2 has a large number of formulations using various types of nanoparticles that were found to be of appropriate size for dispersion in the body. LMWH-based nanocarriers with an emphasis on anticoagulation performance are created with various and acceptable nanosizes, with the anticoagulation performance of the nanocarriers being the most important consideration. The use of conventional anticoagulants has been around for decades in the treatment of a wide variety of illnesses [159]. Compared to heparin and vitamin $\mathrm{K}$ antagonists, direct oral anticoagulants have fewer side effects. A key difficulty connected with these anticoagulants continues to be the lack of a proper laboratory assessment and the absence of a factor "xaban" (Xa) inhibitor reversal medication [160]. LMWHs are anticoagulant agents with excellent efficacy and safety profiles, and they have been investigated for improving outcomes by incorporating various nanocarriers into their formulations and administering them through a variety of administration routes, including intravenous administration [161]. With the use of nanoformulations, it is possible to increase the efficiency of LMWHs by overcoming the major issues that have arisen in the past.

Table 2. Nanoparticles loaded with anticoagulant therapies using different drug delivery systems.

\begin{tabular}{|c|c|c|c|}
\hline Drugs & Types of Nanoparticles & Size Range (nm) & References \\
\hline Low-molecular-weight heparin (LMWH) & \multirow{3}{*}{ Liposomes } & $80-90$ & [159] \\
\hline Ardeparin (LMWH) & & $100-150$ & [162] \\
\hline Enoxaparin (LMWH) & & $40-65$ & [163] \\
\hline Unfractionated (UFH) heparin & \multirow{6}{*}{ Nanogel } & 130 & {$[164]$} \\
\hline Bemiparin (LMWH) & & & \\
\hline Nadroparin (LMWH) & & $150-400$ & [161] \\
\hline Tinzaparin $(\mathrm{LMWH})$ & & & \\
\hline Enoxaparin (LMWH) & & $100-1000$ & [165] \\
\hline Enoxaparin & & $280-320$ & {$[166,167]$} \\
\hline Fondaparinux & Polymeric nanoparticles & $40-65$ & [168] \\
\hline Enoxaparin & & 180-195 & [169] \\
\hline (LMWH) & Solid lipid nanoparticles & $280-380$ & [170] \\
\hline Enoxaparin (LMWH) & \multirow{2}{*}{ Self-nanoemulsifying drug delivery system } & $30-245$ & [167] \\
\hline Rivaroxaban (Factor Xa inhibitor) & & $50-150$ & [160] \\
\hline
\end{tabular}

\subsection{COVID-19 Vaccine Loaded Nanoparticles}

The FDA gave the first emergency use permit ever given to a coronavirus vaccine by the United States $[171,172]$. BioNTech researchers initiated work on the vaccine in January 2020, on the basis of a genetic molecule called messenger RNA (mRNA). The vaccine includes genetic instructions, known as a spike, for developing a coronavirus protein. The vaccine allows them to produce spike proteins when inserted into cells and are then released into the body and thus provoke an immune system response. Pfizer-BioNTech's vaccines are formed in liposomal nanoparticles (LNPs) or PEGylated liposomes (PEGLip). 
PEGlip are artificial phospholipid vesicles that are effective in stabilizing pharmaceutical products and enhancing their pharmacological properties, and in the case of these COVID-19 vaccines, this liposome formulation enables mRNA to be stabilized, owing to its lability. Moreover, Moderna produces the vaccine from mRNA, but they are yet to market one. Moderna are formulated in PEGylated liposomes (PEGLip). PEGlip are artificial phospholipid vesicles that have proven to be useful in stabilizing drugs and improving their pharmacological properties. Furthermore, the Oxford-AstraZeneca vaccine is based on the genetic instructions of the virus for the construction of spike protein. However, the Oxford vaccine uses double-stranded DNA, unlike the Pfizer-BioNTech and Moderna vaccines, which store the instructions in single-stranded RNA. The researchers attached another virus called adenovirus to the gene for the coronavirus spike protein. Novavax COVID-19 vaccine, also known as Nuvaxovid and Covovax [173] is a subunit COVID-19 vaccination developed by Novavax and the Coalition for Epidemic Preparedness Innovations (CEPI). Nuvaxovid's crucial phase III study data were published in its entirety in December 2021 [174]. NVX-CoV2373 has been characterized as a vaccine against both protein subunits and virus-like particles. $[175,176]$, although the producers call it a "recombinant nanoparticle vaccine". The vaccine is made by engineering a baculovirus with a gene encoding a modified SARS-CoV-2 spike protein. Two proline amino acids were added to the spike protein to stabilize the pre-fusion version of the protein; this same $2 \mathrm{P}$ modification is employed in various other COVID-19 vaccines [177]. A saponin-based adjuvant is included in the formulation $[178,179]$ (Table 3).

Table 3. Characteristics of the Pfizer/BioNTech, Oxford University/AstraZeneca, and Moderna vaccines $[19,179]$.

\begin{tabular}{|c|c|c|c|c|}
\hline Characteristics & Pfizer/BioNTech & $\begin{array}{l}\text { Oxford Univer- } \\
\text { sity/AstraZeneca }\end{array}$ & Moderna & $\begin{array}{l}\text { Nuvaxovid and } \\
\text { Covovax }\end{array}$ \\
\hline Therapeutic indication & $\begin{array}{c}\text { For effective } \\
\text { immunization to } \\
\text { suppress SARS-CoV-2 } \\
\text { virus-induced } \\
\text { COVID-19 in persons } \\
16 \text { years of age } \\
\text { and over. }\end{array}$ & $\begin{array}{c}\text { For effective } \\
\text { immunization for the } \\
\text { prevention of } \\
\text { COVID-19 in persons } \\
18 \text { years of age } \\
\text { and over. }\end{array}$ & $\begin{array}{c}\text { For effective } \\
\text { immunization to } \\
\text { prevent SARS-CoV-2 } \\
\text { virus-induced } \\
\text { COVID-19 in persons } \\
18 \text { years of age and over. }\end{array}$ & $\begin{array}{l}\text { The vaccine is } \\
\text { administered in two } \\
\text { doses and is stable at } \\
\text { refrigerated } \\
\text { temperatures of } 2 \text { to } \\
8^{\circ} \mathrm{C}\left(36 \text { to } 46^{\circ} \mathrm{F}\right) \text {. }\end{array}$ \\
\hline Type of vaccine & $\begin{array}{l}\text { Messenger RNA } \\
\text { (mRNA) }\end{array}$ & Adenovirus vector & $\begin{array}{l}\text { Messenger RNA } \\
\text { (mRNA) }\end{array}$ & $\begin{array}{c}\text { Recombinant } \\
\text { nanoparticle vaccine }\end{array}$ \\
\hline Number of doses & A multidose vial & One dose & Multidose & Multidose \\
\hline Pharmaceutical form & $\begin{array}{c}\text { Concentrate for } \\
\text { solution for injection. }\end{array}$ & Solution for injection. & Dispersion for injection. & $\begin{array}{l}\text { Dispersion for } \\
\text { injection. }\end{array}$ \\
\hline Dosage schedule & $\begin{array}{c}\text { Two doses }(0.3 \mathrm{~mL} \\
\text { each) with an interval } \\
\text { of between } 3 \text { to } \\
12 \text { weeks. }\end{array}$ & $\begin{array}{c}\text { Two doses }(0.5 \mathrm{~mL} \\
\text { each) with an interval } \\
\text { of between } 4 \text { and } \\
12 \text { weeks. }\end{array}$ & $\begin{array}{l}\text { Two doses ( } 0.5 \mathrm{~mL} \text { each). } \\
\text { It is recommended that } \\
\text { the second dose be } \\
\text { administered } 28 \text { days } \\
\text { after the first dose. }\end{array}$ & $\begin{array}{l}\text { The vaccine requires } \\
\text { two doses and is stable } \\
\text { at } 2 \text { to } 8{ }^{\circ} \mathrm{C} \text { ( } 36 \text { to } \\
46^{\circ} \mathrm{F} \text { ) refrigerated } \\
\text { temperatures. }\end{array}$ \\
\hline
\end{tabular}

\subsection{Coagulation System Activation and COVID-19 Vaccines}

Many vaccines were manufactured after extensive research on COVID-19 infection, and these vaccines have spread all over the world [180-182]. Moreover, regarding the uncommon side effects following the use of COVID-19 vaccines such as anaphylaxis [183], new reports have found thrombosis with thrombocytopenia syndrome (TTS)-associated venous and arterial thromboembolism [184]. Two common vaccines associated with TTS are Oxford-AstraZeneca or Vaxzevria (ChAdOx1nCoV-19) and Johnson and Johnson (AD26.COV2•S) [185]. Both vaccines contain chimpanzee (ChAdOx1nCoV-19) or human (AD26.COV2•S) recombinant adenovirus vectors that encode the skeletal protein 
of SARS-CoV-2 [186]. In March 2021, several European countries stopped providing the Oxford-AstraZeneca vaccine due to TTS concerns [187]. Reports have shown that among the 34 million people vaccinated by Oxford-AstraZeneca in Europe, 169 cases of cerebral venous thrombosis and 53 cases of visceral venous thrombosis with TTS were recorded [188]. In addition, in the USA, the FDA suspended Johnson and Johnson vaccines in April 2021 due to TTS concerns [189]. Out of 6.8 million people vaccinated by Johnson and Johnson in the USA, 15 cases of thrombosis have been reported. However, no cases of TTS have been described using mRNA vaccines such as Pfizer-BioNTech and Moderna [190]. Considerably, the European Medicines Agency and the Centers for Disease Control and Prevention (CDC) have reported that the benefits of the Oxford-AstraZeneca and Johnson and Johnson vaccines outweigh their risks, including TTS [190]. Moreover, the efficacy of AstraZeneca vaccine in terms of the strong reduction in hospitalizations and death caused by COVID-19 infection, according to the European Medicines Committee (EMA), far outweighs the potential for TTS [191]. Although the mechanism of TTS is not yet known, it is likely to be through the formation of antibodies that act against platelet antigens, resulting in the activation and a large aggregation of platelets, which reduces the number of platelets and leads to thrombosis [187]. Another hypothesis is this: when the adenovirus reaches the blood, it stimulates a conflicting immune response, which leads to platelet activation and decreases the level of ACE2 enzyme on the surface of endothelial cells. Platelet activation could also lead to NET, which results in augmented thrombotic threat [192].

Fever, muscle pain, fatigue, and headache are the early symptoms of COVID-19 vaccines [192]. TTS should be considered in each of the following: headache persisting for more than 3 days, leg swelling, abdominal pain, shortness of breath, chest pain, leg pain, or vomiting after receiving either Oxford-AstraZeneca or Johnson and Johnson vaccines [2]. Complete blood count (CBC), D-dimer, fibrinogen, coagulation panel, and PF4-heparin ELISA are the most important diagnostic tools for TTS cases [190]. To date, important indications in reported cases are increased levels of PF4-heparin ELISA and D-dimer with decreased platelet count and fibrinogen levels [192]. It is advisable to consult with hematologists when there is a suspicion of the presence of TTS in the persons receiving the vaccine.

\section{Conclusions}

In conclusion, hypercoagulability is one of the risk factors that lead to poor outcomes of viral infections in general, and in COVID-19 in particular. Furthermore, hypofibrinolysis is a common feature in patients with COVID-19 infection, and the degree of fibrinolysis inhibition depends on the severity of the infection. It is worth noting that the use carefully controlled doses of anticoagulant therapy, to reduce the risk hypercoagulability in COVID-19 patients, is considered one of the important positive practices. However, caution should be exercised when using anticoagulants in COVID-19 patients, especially those with hereditary coagulation disorders. Other important points to be considered are the promising anticoagulant potential of natural sources of drugs, which is attributable to their safety and diversified mechanisms of action, as well as the promising applications of nanoparticles technology in the design of COVID-19 vaccines and drugs.

\section{Compliance with Ethical Standards}

The review proposal was approved by Al-Azhar University ethical committee and performed in accordance with the regulations of the international guide for the care and use of laboratory animals.

Author Contributions: Conceptualization, M.S.A.-B. and A.A.H.A.; Data curation, M.S.A.-B., E.A., M.G.E., N.I.M., H.A.M., W.M.A. and A.A.H.A.; Formal analysis, M.S.A.-B. and A.A.H.A.; Methodology, M.S.A.-B., E.A., M.G.E., N.I.M., H.A.M., W.M.A. and A.A.H.A.; Resources, M.S.A.-B. and A.A.H.A.; Software, M.S.A.-B., E.A., M.G.E., N.I.M., H.A.M., W.M.A. and A.A.H.A.; Validation, M.S.A.-B. and A.A.H.A.; Visualization, M.S.A.-B. and A.A.H.A.; Writing-original draft, M.S.A.-B., E.A., M.G.E., N.I.M., H.A.M., W.M.A. and A.A.H.A.; Writing-review \& editing, M.S.A.-B., E.A., 
M.G.E., N.I.M., H.A.M., W.M.A. and A.A.H.A. All authors have read and agreed to the published version of the manuscript.

Funding: The author declare that no fund was obtained for conducting this study.

Institutional Review Board Statement: Not applicable.

Informed Consent Statement: The authors declare that no research was conducted on human participants or animals for this study.

Acknowledgments: The researchers would like to thank the Deanship of Scientific Research, Qassim University for funding the publication of this project. The authors also thank Qassim University for providing technical support.

Conflicts of Interest: The authors declare no conflict of interest.

\section{References}

1. Guan, W.J.; Ni, Z.Y.; Hu, Y.; Liang, W.H.; Ou, C.Q.; He, J.X.; Liu, L.; Shan, H.; Lei, C.L.; Hui, D.S.C.; et al. Clinical Characteristics of Coronavirus Disease 2019 in China. N. Engl. J. Med. 2020, 382, 1708-1720. [CrossRef] [PubMed]

2. Abdellatif, A.A.H.; Khan, R.A.; Alhowail, A.H.; Alqasoumi, A.; Sajid, S.M.; Mohammed, A.M.; Alsharidah, M.; Al Rugaie, O.; Mousa, A.M. Octreotide-conjugated silver nanoparticles for active targeting of somatostatin receptors and their application in a nebulized rat model. Nanotechnol. Rev. 2021, 11, 266-283. [CrossRef]

3. Ferrari, M.F.; Raizada, M.K.; Fior-Chadi, D.R. Nicotine modulates the renin-angiotensin system of cultured neurons and glial cells from cardiovascular brain areas of Wistar Kyoto and spontaneously hypertensive rats. J. Mol. Neurosci. 2007, 33, 284-293. [CrossRef] [PubMed]

4. Hamming, I.; Timens, W.; Bulthuis, M.L.; Lely, A.T.; Navis, G.; van Goor, H. Tissue distribution of ACE2 protein, the functional receptor for SARS coronavirus. A first step in understanding SARS pathogenesis. J. Pathol. 2004, 203, 631-637. [CrossRef] [PubMed]

5. Giannis, D.; Ziogas, I.A.; Gianni, P. Coagulation disorders in coronavirus infected patients: COVID-19, SARS-CoV-1, MERS-CoV and lessons from the past. J. Clin. Virol. 2020, 127, 104362. [CrossRef]

6. Ye, Q.; Wang, B.; Mao, J. The pathogenesis and treatment of the 'Cytokine Storm' in COVID-19. J. Infect. 2020, 80, 607-613. [CrossRef]

7. Schnittler, H.J.; Feldmann, H. Viral hemorrhagic fever-A vascular disease? Thromb. Haemost. 2003, 89, 967-972.

8. Zhou, X.; Cheng, Z.; Luo, L.; Zhu, Y.; Lin, W.; Ming, Z.; Chen, W.; Hu, Y. Incidence and impact of disseminated intravascular coagulation in COVID-19 a systematic review and meta-analysis. Thromb. Res. 2021, 201, 23-29. [CrossRef]

9. Wool, G.D.; Miller, J.L. The Impact of COVID-19 Disease on Platelets and Coagulation. Pathobiology 2021, 88, 15-27. [CrossRef]

10. Tang, N.; Li, D.; Wang, X.; Sun, Z. Abnormal coagulation parameters are associated with poor prognosis in patients with novel coronavirus pneumonia. J. Thromb. Haemost. 2020, 18, 844-847. [CrossRef]

11. Lippi, G.; Plebani, M.; Henry, B.M. Thrombocytopenia is associated with severe coronavirus disease 2019 (COVID-19) infections: A meta-analysis. Clin. Chim. Acta 2020, 506, 145-148. [CrossRef]

12. Key, N.S.; Vercellotti, G.M.; Winkelmann, J.C.; Moldow, C.F.; Goodman, J.L.; Esmon, N.L.; Esmon, C.T.; Jacob, H.S. Infection of vascular endothelial cells with herpes simplex virus enhances tissue factor activity and reduces thrombomodulin expression. Proc. Natl. Acad. Sci. USA 1990, 87, 7095-7099. [CrossRef]

13. Subramaniam, S.; Scharrer, I. Procoagulant activity during viral infections. Front. Biosci. 2018, 23, 1060-1081. [CrossRef]

14. De Caterina, R.; D'Ugo, E.; Libby, P. Inflammation and thrombosis-testing the hypothesis with anti-inflammatory drug trials. Thromb. Haemost. 2016, 116, 1012-1021. [CrossRef]

15. Yang, Y.; Tang, H. Aberrant coagulation causes a hyper-inflammatory response in severe influenza pneumonia. Cell. Mol. Immunol. 2016, 13, 432-442. [CrossRef]

16. Neumann, F.J.; Marx, N.; Gawaz, M.; Brand, K.; Ott, I.; Rokitta, C.; Sticherling, C.; Meinl, C.; May, A.; Schomig, A. Induction of cytokine expression in leukocytes by binding of thrombin-stimulated platelets. Circulation 1997, 95, 2387-2394. [CrossRef]

17. Van Gorp, E.C.; Suharti, C.; ten Cate, H.; Dolmans, W.M.; van der Meer, J.W.; ten Cate, J.W.; Brandjes, D.P. Review: Infectious diseases and coagulation disorders. J. Infect. Dis. 1999, 180, 176-186. [CrossRef]

18. Abdellatif, A.A.H.; Mohammed, H.A.; Khan, R.A.; Singh, V.; Bouazzaoui, A.; Yusuf, M.; Akhtar, N.; Khan, M.; Al-Subaiyel, A.; Mohammed, S.A.A.; et al. Nano-scale delivery: A comprehensive review of nano-structured devices, preparative techniques, site-specificity designs, biomedical applications, commercial products, and references to safety, cellular uptake, and organ toxicity. Nanotechnol. Rev. 2021, 10, 1493-1559. [CrossRef]

19. Abdellatif, A.A.H.; Alsowinea, A.F. Approved and marketed nanoparticles for disease targeting and applications in COVID-19. Nanotechnol. Rev. 2021, 10, 1941-1977. [CrossRef]

20. Ilinskaya, A.N.; Dobrovolskaia, M.A. Nanoparticles and the blood coagulation system. Part I: Benefits of nanotechnology. Nanomedicine 2013, 8, 773-784. [CrossRef] 
21. Lorenzano, S.; Inglese, M.; Koudriavtseva, T. Editorial: Role of Coagulation Pathways in Neurological Diseases. Front. Neurol. 2019, 10, 791. [CrossRef]

22. Davalos, D.; Mahajan, K.R.; Trapp, B.D. Brain fibrinogen deposition plays a key role in MS pathophysiology—Yes. Mult. Scler. 2019, 25, 1434-1435. [CrossRef]

23. Plantone, D.; Inglese, M.; Salvetti, M.; Koudriavtseva, T. Corrigendum: A Perspective of Coagulation Dysfunction in Multiple Sclerosis and in Experimental Allergic Encephalomyelitis. Front. Neurol. 2019, 10, 210. [CrossRef]

24. Levi, M. Clinical characteristics of disseminated intravascular coagulation in patients with solid and hematological cancers Thromb. Res. 2018, 164 (Suppl. S1), S77-S81. [CrossRef]

25. Hisada, Y.; Mackman, N. Tissue Factor and Cancer: Regulation, Tumor Growth, and Metastasis. Semin. Thromb. Hemost. 2019, 45, 385-395. [CrossRef]

26. Abdel-Bakky, M.S.; Hammad, M.A.; Walker, L.A.; Ashfaq, M.K. Tissue factor dependent liver injury causes release of retinoid receptors (RXR-alpha and RAR-alpha) as lipid droplets. Biochem. Biophys. Res. Commun. 2011, 410, 146-151. [CrossRef]

27. Abdel-Bakky, M.S.; Helal, G.K.; El-Sayed, E.M.; Alhowail, A.H.; Mansour, A.M.; Alharbi, K.S.; Amin, E.; Allam, S.; Salama, S.A.; Saad, A.S. Silencing of tissue factor by antisense deoxyoligonucleotide mitigates thioacetamide-induced liver injury. Naunyn Schmiedebergs Arch. Pharm. 2020, 393, 1887-1898. [CrossRef]

28. Abdel-Bakky, M.S.; Helal, G.K.; El-Sayed, E.M.; Saad, A.S. Carbon tetrachloride-induced liver injury in mice is tissue factor dependent. Environ. Toxicol. Pharmacol. 2015, 39, 1199-1205. [CrossRef]

29. Abdel-Bakky, M.S.; Hammad, M.A.; Walker, L.A.; Ashfaq, M.K. Silencing of tissue factor by antisense deoxyoligonucleotide prevents monocrotaline/LPS renal injury in mice. Arch. Toxicol. 2011, 85, 1245-1256. [CrossRef]

30. Mahmoud, N.I.; Messiha, B.A.S.; Salehc, I.G.; Abo-Saif, A.A.; Abdel-Bakky, M.S. Interruption of platelets and thrombin function as a new approach against liver fibrosis induced experimentally in rats. Life Sci. 2019, 231, 116522. [CrossRef]

31. Ewees, M.G.; Messiha, B.A.S.; Abo-Saif, A.A.; Bayoumi, A.M.A.; Abdel-Bakky, M.S. Interference with Coagulation Cascade as a Novel Approach to Counteract Cisplatin-Induced Acute Tubular Necrosis; an Experimental Study in Rats. Front. Pharmacol. 2018, 9, 1155. [CrossRef] [PubMed]

32. DeFeo, K.; Hayes, C.; Chernick, M.; Ryn, J.V.; Gilmour, S.K. Use of dabigatran etexilate to reduce breast cancer progression. Cancer Biol. Ther. 2010, 10, 1001-1008. [CrossRef] [PubMed]

33. Nasimuzzaman, M.; Malik, P. Role of the coagulation system in the pathogenesis of sickle cell disease. Blood Adv. 2019, 3, 3170-3180. [CrossRef] [PubMed]

34. Assiri, A.; Al-Tawfiq, J.A.; Al-Rabeeah, A.A.; Al-Rabiah, F.A.; Al-Hajjar, S.; Al-Barrak, A.; Flemban, H.; Al-Nassir, W.N.; Balkhy, H.H.; Al-Hakeem, R.F.; et al. Epidemiological, demographic, and clinical characteristics of 47 cases of Middle East respiratory syndrome coronavirus disease from Saudi Arabia: A descriptive study. Lancet Infect. Dis. 2013, 13, 752-761. [CrossRef]

35. Al-Ani, F.; Chehade, S.; Lazo-Langner, A. Thrombosis risk associated with COVID-19 infection. A scoping review. Thromb. Res. 2020, 192, 152-160. [CrossRef]

36. Tal, S.; Spectre, G.; Kornowski, R.; Perl, L. Venous Thromboembolism Complicated with COVID-19: What Do We Know So Far? Acta Haematol. 2020, 143, 417-424. [CrossRef]

37. Tang, N.; Bai, H.; Chen, X.; Gong, J.; Li, D.; Sun, Z. Anticoagulant treatment is associated with decreased mortality in severe coronavirus disease 2019 patients with coagulopathy. J. Thromb. Haemost. 2020, 18, 1094-1099. [CrossRef]

38. Zhou, F.; Yu, T.; Du, R.; Fan, G.; Liu, Y.; Liu, Z.; Xiang, J.; Wang, Y.; Song, B.; Gu, X.; et al. Clinical course and risk factors for mortality of adult inpatients with COVID-19 in Wuhan, China: A retrospective cohort study. Lancet 2020, 395, $1054-1062$. [CrossRef]

39. Paessler, S.; Walker, D.H. Pathogenesis of the viral hemorrhagic fevers. Annu. Rev. Pathol. 2013, 8, 411-440. [CrossRef]

40. Falasca, L.; Agrati, C.; Petrosillo, N.; Di Caro, A.; Capobianchi, M.R.; Ippolito, G.; Piacentini, M. Molecular mechanisms of Ebola virus pathogenesis: Focus on cell death. Cell Death Differ. 2015, 22, 1250-1259. [CrossRef]

41. Wang, Z.F.; Su, F.; Lin, X.J.; Dai, B.; Kong, L.F.; Zhao, H.W.; Kang, J. Serum D-dimer changes and prognostic implication in 2009 novel influenza A(H1N1). Thromb. Res. 2011, 127, 198-201. [CrossRef]

42. Borges, A.H.; O'Connor, J.L.; Phillips, A.N.; Baker, J.V.; Vjecha, M.J.; Losso, M.H.; Klinker, H.; Lopardo, G.; Williams, I.; Lundgren, J.D.; et al. Factors associated with D-dimer levels in HIV-infected individuals. PLoS ONE 2014, 9, e90978. [CrossRef]

43. Assinger, A. Platelets and infection-An emerging role of platelets in viral infection. Front. Immunol. 2014, 5, 649. [CrossRef]

44. Seyoum, M.; Enawgaw, B.; Melku, M. Human blood platelets and viruses: Defense mechanism and role in the removal of viral pathogens. Thromb. J. 2018, 16, 16. [CrossRef]

45. Lee, N.; Hui, D.; Wu, A.; Chan, P.; Cameron, P.; Joynt, G.M.; Ahuja, A.; Yung, M.Y.; Leung, C.B.; To, K.F.; et al. A major outbreak of severe acute respiratory syndrome in Hong Kong. N. Engl. J. Med. 2003, 348, 1986-1994. [CrossRef]

46. Wong, R.S.; Wu, A.; To, K.F.; Lee, N.; Lam, C.W.; Wong, C.K.; Chan, P.K.; Ng, M.H.; Yu, L.M.; Hui, D.S.; et al. Haematological manifestations in patients with severe acute respiratory syndrome: Retrospective analysis. BMJ 2003, 326, 1358-1362. [CrossRef]

47. Yang, M.; Ng, M.H.; Li, C.K. Thrombocytopenia in patients with severe acute respiratory syndrome (review). Hematology 2005, 10, 101-105. [CrossRef]

48. Qu, R.; Ling, Y.; Zhang, Y.H.; Wei, L.Y.; Chen, X.; Li, X.M.; Liu, X.Y.; Liu, H.M.; Guo, Z.; Ren, H.; et al. Platelet-to-lymphocyte ratio is associated with prognosis in patients with coronavirus disease-19. J. Med. Virol. 2020, 92, 1533-1541. [CrossRef] 
49. Polycarpou, A.; Howard, M.; Farrar, C.A.; Greenlaw, R.; Fanelli, G.; Wallis, R.; Klavinskis, L.S.; Sacks, S. Rationale for targeting complement in COVID-19. EMBO Mol. Med. 2020, 12, e12642. [CrossRef]

50. Wang, Y.; Hao, Q.; Florence, J.M.; Jung, B.G.; Kurdowska, A.K.; Samten, B.; Idell, S.; Tang, H. Influenza Virus Infection Induces ZBP1 Expression and Necroptosis in Mouse Lungs. Front. Cell. Infect. Microbiol. 2019, 9, 286. [CrossRef]

51. Bhagat, S.; Biswas, I.; Ahmed, R.; Khan, G.A. Hypoxia induced up-regulation of tissue factor is mediated through extracellular RNA activated Toll-like receptor 3-activated protein 1 signalling. Blood Cells Mol. Dis. 2020, 84, 102459. [CrossRef]

52. Chen, N.; Zhou, M.; Dong, X.; Qu, J.; Gong, F.; Han, Y.; Qiu, Y.; Wang, J.; Liu, Y.; Wei, Y.; et al. Epidemiological and clinical characteristics of 99 cases of 2019 novel coronavirus pneumonia in Wuhan, China: A descriptive study. Lancet 2020, 395, 507-513. [CrossRef]

53. Yin, S.; Huang, M.; Li, D.; Tang, N. Difference of coagulation features between severe pneumonia induced by SARS-CoV2 and non-SARS-CoV2. J. Thromb. Thrombolysis 2020, 49, 1-9. [CrossRef]

54. Spiezia, L.; Boscolo, A.; Poletto, F.; Cerruti, L.; Tiberio, I.; Campello, E.; Navalesi, P.; Simioni, P. COVID-19-Related Severe Hypercoagulability in Patients Admitted to Intensive Care Unit for Acute Respiratory Failure. Thromb. Haemost. 2020, 120, 9981000. [CrossRef]

55. Connors, J.M.; Levy, J.H. COVID-19 and its implications for thrombosis and anticoagulation. Blood 2020, 135, 2033-2040. [CrossRef]

56. Escher, R.; Breakey, N.; Lammle, B. Severe COVID-19 infection associated with endothelial activation. Thromb. Res. 2020, 190, 62. [CrossRef]

57. Panigada, M.; Bottino, N.; Tagliabue, P.; Grasselli, G.; Novembrino, C.; Chantarangkul, V.; Pesenti, A.; Peyvandi, F.; Tripodi, A. Hypercoagulability of COVID-19 patients in intensive care unit: A report of thromboelastography findings and other parameters of hemostasis. J. Thromb. Haemost. 2020, 18, 1738-1742. [CrossRef]

58. Agrawal, A.; Zhuo, H.; Brady, S.; Levitt, J.; Steingrub, J.; Siegel, M.D.; Soto, G.; Peterson, M.W.; Chesnutt, M.S.; Matthay, M.A.; et al. Pathogenetic and predictive value of biomarkers in patients with ALI and lower severity of illness: Results from two clinical trials. Am. J. Physiol. Lung Cell. Mol. Physiol. 2012, 303, L634-L639. [CrossRef]

59. Prabhakaran, P.; Ware, L.B.; White, K.E.; Cross, M.T.; Matthay, M.A.; Olman, M.A. Elevated levels of plasminogen activator inhibitor-1 in pulmonary edema fluid are associated with mortality in acute lung injury. Am. J. Physiol. Lung Cell. Mol. Physiol. 2003, 285, L20-L28. [CrossRef]

60. Sapru, A.; Calfee, C.S.; Liu, K.D.; Kangelaris, K.; Hansen, H.; Pawlikowska, L.; Ware, L.B.; Alkhouli, M.F.; Abbott, J.; Matthay, M.A.; et al. Plasma soluble thrombomodulin levels are associated with mortality in the acute respiratory distress syndrome. Intensive Care Med. 2015, 41, 470-478. [CrossRef]

61. Thompson, B.T. Acute respiratory distress syndrome in another 50 years: Historical footnote or persistent malady? Curr. Opin. Crit. Care 2017, 23, 1-3. [CrossRef] [PubMed]

62. Ware, L.B.; Matthay, M.A.; Parsons, P.E.; Thompson, B.T.; Januzzi, J.L.; Eisner, M.D.; The National Heart, Lung, Blood Institute Acute Respiratory Distress Syndrome Clinical Trials Network. Pathogenetic and prognostic significance of altered coagulation and fibrinolysis in acute lung injury/acute respiratory distress syndrome. Crit. Care Med. 2007, 35, 1821-1828. [CrossRef] [PubMed]

63. Bastarache, J.A.; Wang, L.; Geiser, T.; Wang, Z.; Albertine, K.H.; Matthay, M.A.; Ware, L.B. The alveolar epithelium can initiate the extrinsic coagulation cascade through expression of tissue factor. Thorax 2007, 62, 608-616. [CrossRef] [PubMed]

64. McFadyen, J.D.; Stevens, H.; Peter, K. The Emerging Threat of (Micro)Thrombosis in COVID-19 and Its Therapeutic Implications. Circ. Res. 2020, 127, 571-587. [CrossRef]

65. Becker, R.C. COVID-19 update: Covid-19-associated coagulopathy. J. Thromb. Thrombolysis 2020, 50, 54-67. [CrossRef]

66. Authorization, F.a.D.A.i.a.e.u. Janssen COVID-19 Vaccine Frequently Asked Questions. 2021. Available online: https: //www.fda.gov/emergency-preparedness-and-response/coronavirus-disease-2019-covid-19/janssen-covid-19-vaccinefrequently-asked-questions (accessed on 27 November 2021).

67. Agency, E.M. Signal Assessment Report on Embolic and Thrombotic Events (SMQ) with COVID-19 Vaccine (ChAdOx1-S [recombinant])-COVID-19 Vaccine AstraZeneca (Other Viral Vaccines). 2021. Available online: https://www.ema.europa.eu/en/ documents / prac-recommendation/signal-assessment-report-embolic-thrombotic-events-smq-covid-19-vaccine-chadox1-srecombinant_en.pdf (accessed on 27 November 2021).

68. Talotta, R.; Robertson, E.S. Antiphospholipid antibodies and risk of post-COVID-19 vaccination thrombophilia: The straw that breaks the camel's back? Cytokine Growth Factor Rev. 2021, 60, 52-60. [CrossRef]

69. Levy, J.H.; Iba, T.; Olson, L.B.; Corey, K.M.; Ghadimi, K.; Connors, J.M. COVID-19: Thrombosis, thromboinflammation, and anticoagulation considerations. Int. J. Lab. Hematol. 2021, 43 (Suppl. S1), 29-35. [CrossRef]

70. Kwaan, H.C. From fibrinolysis to the plasminogen-plasmin system and beyond: A remarkable growth of knowledge, with personal observations on the history of fibrinolysis. Semin. Thromb. Hemost. 2014, 40, 585-591. [CrossRef]

71. Kwaan, H.C.; Lindholm, P.F. The Central Role of Fibrinolytic Response in COVID-19-A Hematologist's Perspective. Int. J. Mol. Sci. 2021, 22, 1283. [CrossRef]

72. Komissarov, A.A.; Rahman, N.; Lee, Y.C.G.; Florova, G.; Shetty, S.; Idell, R.; Ikebe, M.; Das, K.; Tucker, T.A.; Idell, S. Fibrin turnover and pleural organization: Bench to bedside. Am. J. Physiol. Lung Cell. Mol. Physiol. 2018, 314, L757-L768. [CrossRef] 
73. Tucker, T.; Idell, S. Plasminogen-plasmin system in the pathogenesis and treatment of lung and pleural injury. Semin. Thromb. Hemost. 2013, 39, 373-381. [CrossRef]

74. Schmitt, F.C.F.; Manolov, V.; Morgenstern, J.; Fleming, T.; Heitmeier, S.; Uhle, F.; Al-Saeedi, M.; Hackert, T.; Bruckner, T.; Schochl, H.; et al. Acute fibrinolysis shutdown occurs early in septic shock and is associated with increased morbidity and mortality: Results of an observational pilot study. Ann. Intensive Care 2019, 9, 19. [CrossRef]

75. Panigada, M.; Zacchetti, L.; L'Acqua, C.; Cressoni, M.; Anzoletti, M.B.; Bader, R.; Protti, A.; Consonni, D.; D'Angelo, A.; Gattinoni, L. Assessment of Fibrinolysis in Sepsis Patients with Urokinase Modified Thromboelastography. PLoS ONE 2015, 10, e0136463. [CrossRef]

76. Bhandary, Y.P.; Shetty, S.K.; Marudamuthu, A.S.; Ji, H.L.; Neuenschwander, P.F.; Boggaram, V.; Morris, G.F.; Fu, J.; Idell, S.; Shetty, S. Regulation of lung injury and fibrosis by p53-mediated changes in urokinase and plasminogen activator inhibitor-1. Am. J. Pathol. 2013, 183, 131-143. [CrossRef]

77. Puthusseri, B.; Marudamuthu, A.; Tiwari, N.; Fu, J.; Idell, S.; Shetty, S. Regulation of p53-mediated changes in the uPA-fibrinolytic system and in lung injury by loss of surfactant protein C expression in alveolar epithelial cells. Am. J. Physiol. Lung Cell. Mol. Physiol. 2017, 312, L783-L796. [CrossRef]

78. Gouda, M.M.; Shaikh, S.B.; Bhandary, Y.P. Inflammatory and Fibrinolytic System in Acute Respiratory Distress Syndrome. Lung 2018, 196, 609-616. [CrossRef]

79. Kalluri, R.; Neilson, E.G. Epithelial-mesenchymal transition and its implications for fibrosis. J. Clin. Investig. 2003, 112, 1776-1784. [CrossRef]

80. Lin, L.; Lu, L.; Cao, W.; Li, T. Hypothesis for potential pathogenesis of SARS-CoV-2 infection-a review of immune changes in patients with viral pneumonia. Emerg. Microbes Infect. 2020, 9, 727-732. [CrossRef]

81. Jaimes, F.; De La Rosa, G.; Morales, C.; Fortich, F.; Arango, C.; Aguirre, D.; Munoz, A. Unfractioned heparin for treatment of sepsis: A randomized clinical trial (The HETRASE Study). Crit. Care Med. 2009, 37, 1185-1196. [CrossRef]

82. Bikdeli, B.; Madhavan, M.V.; Jimenez, D.; Chuich, T.; Dreyfus, I.; Driggin, E.; Nigoghossian, C.; Ageno, W.; Madjid, M.; Guo, Y.; et al. COVID-19 and Thrombotic or Thromboembolic Disease: Implications for Prevention, Antithrombotic Therapy, and Follow-Up: JACC State-of-the-Art Review. J. Am. Coll. Cardiol. 2020, 75, 2950-2973. [CrossRef]

83. Thachil, J.; Tang, N.; Gando, S.; Falanga, A.; Cattaneo, M.; Levi, M.; Clark, C.; Iba, T. ISTH interim guidance on recognition and management of coagulopathy in COVID-19. J. Thromb. Haemost. 2020, 18, 1023-1026. [CrossRef]

84. Galluccio, F.; Ergonenc, T.; Garcia Martos, A.; Allam, A.E.; Perez-Herrero, M.; Aguilar, R.; Emmi, G.; Spinicci, M.; Terrancle Juan, I.; Fajardo-Perez, M. Treatment algorithm for COVID-19: A multidisciplinary point of view. Clin. Rheumatol. 2020, 39, 2077-2084. [CrossRef]

85. Goeijenbier, M.; van Wissen, M.; van de Weg, C.; Jong, E.; Gerdes, V.E.; Meijers, J.C.; Brandjes, D.P.; van Gorp, E.C. Review: Viral infections and mechanisms of thrombosis and bleeding. J. Med. Virol. 2012, 84, 1680-1696. [CrossRef]

86. Furie, B.; Furie, B.C. In vivo thrombus formation. J. Thromb. Haemost. 2007, 5 (Suppl. S1), 12-17. [CrossRef]

87. Chen, C.; Yang, F.Q.; Zhang, Q.; Wang, F.Q.; Hu, Y.J.; Xia, Z.N. Natural Products for Antithrombosis. Evid.-Based Complement. Altern. Med. 2015, 2015, 876426. [CrossRef]

88. Fuentes, E.; Guzmán, L.; Alarcón, M.; Moore, R.; Palomo, I. Thrombolytic/fibrinolytic mechanism of natural products. In Fibrinolysis and Thrombolysis; IntechOpen Ltd.: London, UK, 2014. [CrossRef]

89. Kuznetsova, T.A.; Andryukov, B.G.; Makarenkova, I.D.; Zaporozhets, T.S.; Besednova, N.N.; Fedyanina, L.N.; Kryzhanovsky, S.P.; Shchelkanov, M.Y. The Potency of Seaweed Sulfated Polysaccharides for the Correction of Hemostasis Disorders in COVID-19. Molecules 2021, 26, 2618. [CrossRef]

90. Carvalhal, F.; Cristelo, R.R.; Resende, D.; Pinto, M.M.M.; Sousa, E.; Correia-da-Silva, M. Antithrombotics from the Sea: Polysaccharides and Beyond. Mar. Drugs 2019, 17, 170. [CrossRef]

91. Lee, M.H.; Son, Y.K.; Han, Y.N. Tissue factor inhibitory flavonoids from the fruits of Chaenomeles sinensis. Arch. Pharm. Res. 2002, 25, 842-850. [CrossRef]

92. Lee, M.H.; Son, Y.K.; Han, Y.N. Tissue factor inhibitory sesquiterpene glycoside from Eriobotrya japonica. Arch. Pharm. Res. 2004, 27, 619-623. [CrossRef]

93. Ku, S.-K.; Yoo, H.; Zhou, W.; Na, M.; Bae, J.-S. Antiplatelet activities of hyperosidein vitroandin vivo. Anim. Cells Syst. 2014, 18, 204-209. [CrossRef]

94. Wang, Y.; Shao, J.; Yao, S.; Zhang, S.; Yan, J.; Wang, H.; Chen, Y. Study on the antithrombotic activity of Umbilicaria esculenta polysaccharide. Carbohydr. Polym. 2014, 105, 231-236. [CrossRef] [PubMed]

95. Ku, S.K.; Bae, J.S. Antiplatelet, anticoagulant, and profibrinolytic activities of withaferin A. Vasc. Pharm. 2014, 60, 120-126. [CrossRef] [PubMed]

96. Ku, S.K.; Bae, J.S. Antithrombotic activities of wogonin and wogonoside via inhibiting platelet aggregation. Fitoterapia 2014, 98, 27-35. [CrossRef] [PubMed]

97. Pawlaczyk, I.; Czerchawski, L.; Kuliczkowski, W.; Karolko, B.; Pilecki, W.; Witkiewicz, W.; Gancarz, R. Anticoagulant and anti-platelet activity of polyphenolic-polysaccharide preparation isolated from the medicinal plant Erigeron canadensis L. Thromb. Res. 2011, 127, 328-340. [CrossRef] 
98. Fernandez, P.V.; Quintana, I.; Cerezo, A.S.; Caramelo, J.J.; Pol-Fachin, L.; Verli, H.; Estevez, J.M.; Ciancia, M. Anticoagulant activity of a unique sulfated pyranosic (1->3)-beta-L-arabinan through direct interaction with thrombin. J. Biol. Chem. 2013, 288, 223-233. [CrossRef] [PubMed]

99. Ayodele, O.O.; Onajobi, F.D.; Osoniyi, O. In vitro anticoagulant effect of Crassocephalum crepidioides leaf methanol extract and fractions on human blood. J. Exp. Pharmacol. 2019, 11, 99-107. [CrossRef]

100. Amroyan, E.; Gabrielian, E.; Panossian, A.; Wikman, G.; Wagner, H. Inhibitory effect of andrographolide from Andrographis paniculata on PAF-induced platelet aggregation. Phytomedicine 1999, 6, 27-31. [CrossRef]

101. Kim, S.Y.; Yun-Choi, H.S. Platelet anti-aggregating activities of bupleurumin from the aerial parts of Bupleurum falcatum. Arch. Pharm. Res. 2007, 30, 561-564. [CrossRef]

102. Maione, F.; De Feo, V.; Caiazzo, E.; De Martino, L.; Cicala, C.; Mascolo, N. Tanshinone IIA, a major component of Salvia milthorriza Bunge, inhibits platelet activation via Erk-2 signaling pathway. J. Ethnopharmacol. 2014, 155, 1236-1242. [CrossRef]

103. Yasin, M.; Hussain Janbaz, K.; Imran, I.; Gilani, A.U.; Bashir, S. Pharmacological studies on the antispasmodic, bronchodilator and anti-platelet activities of Abies webbiana. Phytother. Res. 2014, 28, 1182-1187. [CrossRef]

104. Gadi, D.; Bnouham, M.; Aziz, M.; Ziyyat, A.; Legssyer, A.; Legrand, C.; Lafeve, F.F.; Mekhfi, H. Parsley extract inhibits in vitro and ex vivo platelet aggregation and prolongs bleeding time in rats. J. Ethnopharmacol. 2009, 125, 170-174. [CrossRef]

105. Ansari, V.; Mujahid, M.; Siddiqui, H.; Dixit, R.; Singh, K. In vitro study for antiplatelet activity of 'Kalonji'(Nigella sativa) extracts using aspirin as standard. J. Chem. Pharm. Res. 2016, 8, 182-185.

106. Lee, B.J.; Jo, I.Y.; Bu, Y.; Park, J.W.; Maeng, S.; Kang, H.; Jang, W.; Hwang, D.S.; Lee, W.; Min, K.; et al. Antiplatelet effects of Spatholobus suberectus via inhibition of the glycoprotein IIb/IIIa receptor. J. Ethnopharmacol. 2011, 134, 460-467. [CrossRef]

107. Allison, G.L.; Lowe, G.M.; Rahman, K. Aged garlic extract inhibits platelet activation by increasing intracellular cAMP and reducing the interaction of GPIIb/IIIa receptor with fibrinogen. Life Sci. 2012, 91, 1275-1280. [CrossRef]

108. Zhang, B.; Long, K. Effects of glaucocalyxin A on aggregation and cAMP levels of rabbit platelets in vitro. Zhongguo Yao Li Xue Bao 1993, 14, 347-350.

109. Мa, C.; Yao, Y.; Yue, Q.X.; Zhou, X.W.; Yang, P.Y.; Wu, W.Y.; Guan, S.H.; Jiang, B.H.; Yang, M.; Liu, X.; et al. Differential proteomic analysis of platelets suggested possible signal cascades network in platelets treated with salvianolic acid B. PLoS ONE 2011, 6, e14692. [CrossRef]

110. Jalil, J.; Jantan, I.; Ghani, A.A.; Murad, S. Platelet-activating factor (PAF) antagonistic activity of a new biflavonoid from Garcinia nervosa var. pubescens King. Molecules 2012, 17, 10893-10901. [CrossRef]

111. Stead, P.; Hiscox, S.; Robinson, P.S.; Pike, N.B.; Sidebottom, P.J.; Roberts, A.D.; Taylor, N.L.; Wright, A.E.; Pomponi, S.A.; Langley, D. Eryloside F, a novel penasterol disaccharide possessing potent thrombin receptor antagonist activity. Bioorganic Med. Chem. Lett. 2000, 10, 661-664. [CrossRef]

112. Iwashita, M.; Oka, N.; Ohkubo, S.; Saito, M.; Nakahata, N. Piperlongumine, a constituent of Piper longum L., inhibits rabbit platelet aggregation as a thromboxane A2 receptor antagonist. Eur. J. Pharmacol. 2007, 570, 38-42. [CrossRef]

113. Alvarado-Castillo, C.; Estrada, O.; Carvajal, E. Pomolic acid, triterpenoid isolated from Licania pittieri, as competitive antagonist of ADP-induced aggregation of human platelets. Phytomedicine 2012, 19, 484-487. [CrossRef]

114. Xiang, K.; Liu, G.; Zhou, Y.J.; Hao, H.Z.; Yin, Z.; He, A.D.; Da, X.W.; Xiang, J.Z.; Wang, J.L.; Ming, Z.Y. 2,3,5,4'-tetrahydroxystilbene2-O-beta-D-glucoside (THSG) attenuates human platelet aggregation, secretion and spreading in vitro. Thromb. Res. 2014, 133, 211-217. [CrossRef]

115. Kong, Y.; Huo, J.L.; Xu, W.; Xiong, J.; Li, Y.M.; Wu, W.T. A novel anti-platelet aggregation tripeptide from Agkistrodon acutus venom: Isolation and characterization. Toxicon 2009, 54, 103-109. [CrossRef]

116. Park, M.K.; Rhee, Y.H.; Lee, H.J.; Lee, E.O.; Kim, K.H.; Park, M.J.; Jeon, B.H.; Shim, B.S.; Jung, C.H.; Choi, S.H.; et al. Antiplatelet and antithrombotic activity of indole-3-carbinol in vitro and in vivo. Phytother. Res. 2008, 22, 58-64. [CrossRef]

117. Moharam, B.A.; Jantan, I.; Ahmad, F.; Jalil, J. Antiplatelet aggregation and platelet activating factor (PAF) receptor antagonistic activities of the essential oils of five Goniothalamus species. Molecules 2010, 15, 5124-5138. [CrossRef]

118. Sheu, J.-R.; Kan, Y.-C.; Hung, W.-C.; Ko, W.-C.; Yen, M.-H. Mechanisms Involved in the Antiplatelet Activity of Tetramethylpyrazine in Human Platelets. Thromb. Res. 1997, 88, 259-270. [CrossRef]

119. Jeon, W.K.; Lee, J.H.; Kim, H.K.; Lee, A.Y.; Lee, S.O.; Kim, Y.S.; Ryu, S.Y.; Kim, S.Y.; Lee, Y.J.; Ko, B.S. Anti-platelet effects of bioactive compounds isolated from the bark of Rhus verniciflua Stokes. J. Ethnopharmacol. 2006, 106, 62-69. [CrossRef]

120. Lee, D.H.; Kwon, H.W.; Kim, H.H.; Lim, D.H.; Nam, G.S.; Shin, J.H.; Kim, Y.Y.; Kim, J.L.; Lee, J.J.; Kwon, H.K.; et al. Cordycepinenriched WIB801C from Cordyceps militaris inhibits ADP-induced $\left[\mathrm{Ca}^{2+}\right]_{\mathrm{i}}$ mobilization and fibrinogen binding via phosphorylation of IP 3R and VASP. Arch. Pharm. Res. 2015, 38, 81-97. [CrossRef]

121. Cho, H.J.; Shon, Y.H.; Nam, K.S. Ginkgolide C inhibits platelet aggregation in cAMP- and cGMP-dependent manner by activating MMP-9. Biol. Pharm. Bull. 2007, 30, 2340-2344. [CrossRef]

122. Park, J.Y.; Oh, W.J.; Kim, M.J.; Kim, T.H.; Cho, J.Y.; Park, H.J.; Lee, I.K.; Kim, S.; Kim, G.S.; Kim, S.K.; et al. Mechanism of anti-platelet activity of Oligoporus tephroleucus oligoporin A: Involvement of extracellular signal-regulated kinase phosphorylation and cyclic nucleotide elevation. Platelets 2012, 23, 376-385. [CrossRef]

123. Yang, L.; Qian, Z.; Yang, Y.; Sheng, L.; Ji, H.; Zhou, C.; Kazi, H.A. Involvement of $\mathrm{Ca}^{2+}$ in the inhibition by crocetin of platelet activity and thrombosis formation. J. Agric. Food Chem. 2008, 56, 9429-9433. [CrossRef] 
124. Kim, K.; Lim, K.M.; Kim, C.W.; Shin, H.J.; Seo, D.B.; Lee, S.J.; Noh, J.Y.; Bae, O.N.; Shin, S.; Chung, J.H. Black soybean extract can attenuate thrombosis through inhibition of collagen-induced platelet activation. J. Nutr. Biochem. 2011, 22, 964-970. [CrossRef] [PubMed]

125. Tsai, T.-H.; Tsai, W.-J.; Chou, C.-J.; Chen, C.-F. Magnolol inhibits collagen-induced platelet serotonin release. Thromb. Res. 1995, 78, 265-270. [CrossRef]

126. Fuentes, E.; Alarcon, M.; Astudillo, L.; Valenzuela, C.; Gutierrez, M.; Palomo, I. Protective mechanisms of guanosine from Solanum lycopersicum on agonist-induced platelet activation: Role of sCD40L. Molecules 2013, 18, 8120-8135. [CrossRef] [PubMed]

127. Xia, Q.; Wang, X.; Xu, D.J.; Chen, X.H.; Chen, F.H. Inhibition of platelet aggregation by curdione from Curcuma wenyujin essential Oil. Thromb. Res. 2012, 130, 409-414. [CrossRef] [PubMed]

128. Lee, D.H.; Kim, Y.J.; Kim, H.H.; Cho, H.J.; Ryu, J.H.; Rhee, M.H.; Park, H.J. Inhibitory effects of epigallocatechin-3-gallate on microsomal cyclooxygenase-1 activity in platelets. Biomol. Ther. 2013, 21, 54-59. [CrossRef] [PubMed]

129. Seo, E.J.; Lee, S.Y.; Kang, S.S.; Jung, Y.S. Zizyphus jujuba and its active component jujuboside B inhibit platelet aggregation. Phytother. Res. 2013, 27, 829-834. [CrossRef]

130. Li, J.; Yu, G.; Fan, J. Alditols and monosaccharides from sorghum vinegar can attenuate platelet aggregation by inhibiting cyclooxygenase-1 and thromboxane-A2 synthase. J. Ethnopharmacol. 2014, 155, 285-292. [CrossRef]

131. Yu, J.Y.; Lee, J.J.; Jung, J.K.; Min, Y.K.; Ma, J.Y.; Kim, T.J.; Lee, M.Y.; Yun, Y.P. Anti-platelet activity of diacetylated obovatol through regulating cyclooxygenase and lipoxygenase activities. Arch. Pharm. Res. 2012, 35, 2191-2198. [CrossRef]

132. Ryu, R.; Jung, U.J.; Kim, H.J.; Lee, W.; Bae, J.S.; Park, Y.B.; Choi, M.S. Anticoagulant and Antiplatelet Activities of Artemisia princeps Pampanini and Its Bioactive Components. Prev. Nutr. Food Sci. 2013, 18, 181-187. [CrossRef]

133. Jin, Y.R.; Han, X.H.; Zhang, Y.H.; Lee, J.J.; Lim, Y.; Chung, J.H.; Yun, Y.P. Antiplatelet activity of hesperetin, a bioflavonoid, is mainly mediated by inhibition of PLC-gamma2 phosphorylation and cyclooxygenase-1 activity. Atherosclerosis 2007, 194, 144-152. [CrossRef]

134. Chang, M.C.; Uang, B.J.; Tsai, C.Y.; Wu, H.L.; Lin, B.R.; Lee, C.S.; Chen, Y.J.; Chang, C.H.; Tsai, Y.L.; Kao, C.J.; et al. Hydroxychavi$\mathrm{col}$, a novel betel leaf component, inhibits platelet aggregation by suppression of cyclooxygenase, thromboxane production and calcium mobilization. Br. J. Pharmacol. 2007, 152, 73-82. [CrossRef]

135. Kim, H.-S.; Zhang, Y.-H.; Fang, L.-H.; Yun, Y.-P.; Lee, H.-K. Effects of tetrandrine and fangchinoline on human platelet aggregation and thromboxane B2 formation. J. Ethnopharmacol. 1999, 66, 241-246. [CrossRef]

136. Coy, E.D.; Cuca, L.E.; Sefkow, M. COX, LOX and platelet aggregation inhibitory properties of Lauraceae neolignans. Bioorganic Med. Chem. Lett. 2009, 19, 6922-6925. [CrossRef]

137. Abe, M.; Ozawa, Y.; Uda, Y.; Morimitsu, Y.; Nakamura, Y.; Osawa, T. A novel labdane-type trialdehyde from myoga (Zingiber mioga Roscoe) that potently inhibits human platelet aggregation and human 5-lipoxygenase. Biosci. Biotechnol. Biochem. 2006, 70, 2494-2500. [CrossRef]

138. Ju, H.K.; Lee, J.G.; Park, M.K.; Park, S.J.; Lee, C.H.; Park, J.H.; Kwon, S.W. Metabolomic investigation of the anti-platelet aggregation activity of ginsenoside Rk(1) reveals attenuated 12-HETE production. J. Proteome Res. 2012, 11, 4939-4946. [CrossRef]

139. Abdellatif, A.A.H. A plausible way for excretion of metal nanoparticles via active targeting. Drug Dev. Ind. Pharm. 2020, 46, 744-750. [CrossRef]

140. Abdellatif, A.A.H.; Ibrahim, M.A.; Amin, M.A.; Maswadeh, H.; Alwehaibi, M.N.; Al-Harbi, S.N.; Alharbi, Z.A.; Mohammed, H.A.; Mehany, A.B.M.; Saleem, I. Cetuximab Conjugated with Octreotide and Entrapped Calcium Alginate-beads for Targeting Somatostatin Receptors. Sci. Rep. 2020, 10, 4736. [CrossRef]

141. Kemp, M.M.; Kumar, A.; Mousa, S.; Dyskin, E.; Yalcin, M.; Ajayan, P.; Linhardt, R.J.; Mousa, S.A. Gold and silver nanoparticles conjugated with heparin derivative possess anti-angiogenesis properties. Nanotechnology 2009, 20, 455104. [CrossRef]

142. Kang, C.; Gwon, S.; Song, C.; Kang, P.M.; Park, S.C.; Jeon, J.; Hwang, D.W.; Lee, D. Fibrin-Targeted and $\mathrm{H}_{2} \mathrm{O}_{2}-\mathrm{Responsive}$ Nanoparticles as a Theranostics for Thrombosed Vessels. ACS Nano 2017, 11, 6194-6203. [CrossRef]

143. Starmans, L.W.; Moonen, R.P.; Aussems-Custers, E.; Daemen, M.J.; Strijkers, G.J.; Nicolay, K.; Grull, H. Evaluation of iron oxide nanoparticle micelles for magnetic particle imaging (MPI) of thrombosis. PLoS ONE 2015, 10, e0119257. [CrossRef]

144. Suzuki, M.; Bachelet-Violette, L.; Rouzet, F.; Beilvert, A.; Autret, G.; Maire, M.; Menager, C.; Louedec, L.; Choqueux, C.; Saboural, P.; et al. Ultrasmall superparamagnetic iron oxide nanoparticles coated with fucoidan for molecular MRI of intraluminal thrombus. Nanomedicine 2015, 10, 73-87. [CrossRef]

145. Srinivasan, R.; Marchant, R.E.; Gupta, A.S. In vitro and in vivo platelet targeting by cyclic RGD-modified liposomes. J. Biomed. Mater. Res. A 2010, 93, 1004-1015. [CrossRef]

146. Park, K.; Lee, G.Y.; Kim, Y.S.; Yu, M.; Park, R.W.; Kim, I.S.; Kim, S.Y.; Byun, Y. Heparin-deoxycholic acid chemical conjugate as an anticancer drug carrier and its antitumor activity. J. Control. Release 2006, 114, 300-306. [CrossRef]

147. Khaliq, N.U.; Sandra, F.C.; Park, D.Y.; Lee, J.Y.; Oh, K.S.; Kim, D.; Byun, Y.; Kim, I.S.; Kwon, I.C.; Kim, S.Y.; et al. Doxorubicin/heparin composite nanoparticles for caspase-activated prodrug chemotherapy. Biomaterials 2016, 101, 131-142. [CrossRef]

148. Abdellatif, A.A.H.; Aldalaen, S.M.; Faisal, W.; Tawfeek, H.M. Somatostatin receptors as a new active targeting sites for nanoparticles. Saudi Pharm. J. 2018, 26, 1051-1059. [CrossRef]

149. Lombardo, D.; Kiselev, M.A.; Caccamo, M.T. Smart Nanoparticles for Drug Delivery Application: Development of Versatile Nanocarrier Platforms in Biotechnology and Nanomedicine. J. Nanomater. 2019, 2019, 3702518. [CrossRef] 
150. Chen, C.; Li, S.; Liu, K.; Ma, G.; Yan, X. Co-Assembly of Heparin and Polypeptide Hybrid Nanoparticles for Biomimetic Delivery and Anti-Thrombus Therapy. Small 2016, 12, 4719-4725. [CrossRef]

151. Joshi, P.; Chakraborty, S.; Dey, S.; Shanker, V.; Ansari, Z.A.; Singh, S.P.; Chakrabarti, P. Binding of chloroquine-conjugated gold nanoparticles with bovine serum albumin. J. Colloid Interface Sci. 2011, 355, 402-409. [CrossRef] [PubMed]

152. Hsu, H.K.; Hsu, K.H.; Cheng, Y.M.; Suen, H.Y.; Peng, S.F. Development and In Vitro Evaluation of Linear PEI-Shelled Heparin/Berberine Nanoparticles in Human Osteosarcoma U-2 OS Cells. Molecules 2018, 23, 3122. [CrossRef] [PubMed]

153. Maslanka Figueroa, S.; Veser, A.; Abstiens, K.; Fleischmann, D.; Beck, S.; Goepferich, A. Influenza A virus mimetic nanoparticles trigger selective cell uptake. Proc. Natl. Acad. Sci. USA 2019, 116, 9831-9836. [CrossRef] [PubMed]

154. Itani, R.; Tobaiqy, M.; Al Faraj, A. Optimizing use of theranostic nanoparticles as a life-saving strategy for treating COVID-19 patients. Theranostics 2020, 10, 5932-5942. [CrossRef]

155. Janardhan, V.; Janardhan, V.; Kalousek, V. COVID-19 as a Blood Clotting Disorder Masquerading as a Respiratory Illness: A Cerebrovascular Perspective and Therapeutic Implications for Stroke Thrombectomy. J. Neuroimaging 2020, 30, 555-561. [CrossRef]

156. O'Leary, K. COVID-19 vaccine and blood clotting. Nat. Med. 2021. [CrossRef]

157. Saei, A.A.; Sharifi, S.; Mahmoudi, M. COVID-19: Nanomedicine Uncovers Blood-Clot Mystery. J. Proteome Res. 2020, 19, 4364-4373. [CrossRef]

158. Patriota, Y.B.G.; Chaves, L.L.; Gocke, E.H.; Severino, P.; Soares, M.F.R.; Soares-Sobrinho, J.L.; Souto, E.B. Applied Nanotechnologies in Anticoagulant Therapy: From Anticoagulants to Coagulation Test Performance of Drug Delivery Systems. Appl. Nano 2021, 2, 98-117. [CrossRef]

159. Song, Y.K.; Hyun, S.Y.; Kim, H.T.; Kim, C.K.; Oh, J.M. Transdermal delivery of low molecular weight heparin loaded in flexible liposomes with bioavailability enhancement: Comparison with ethosomes. J. Microencapsul. 2011, 28, 151-158. [CrossRef]

160. Xue, X.; Cao, M.; Ren, L.; Qian, Y.; Chen, G. Preparation and Optimization of Rivaroxaban by Self-Nanoemulsifying Drug Delivery System (SNEDDS) for Enhanced Oral Bioavailability and No Food Effect. AAPS PharmSciTech 2018, 19, 1847-1859. [CrossRef]

161. Loira-Pastoriza, C.; Sapin-Minet, A.; Diab, R.; Grossiord, J.L.; Maincent, P. Low molecular weight heparin gels, based on nanoparticles, for topical delivery. Int. J. Pharm. 2012, 426, 256-262. [CrossRef]

162. Bai, S.; Ahsan, F. Inhalable liposomes of low molecular weight heparin for the treatment of venous thromboembolism. J. Pharm. Sci. 2010, 99, 4554-4564. [CrossRef]

163. Lavanya, N.; Muzib, Y.I.; Aukunuru, J.; Balekari, U. Preparation and evaluation of a novel oral delivery system for low molecular weight heparin. Int. J. Pharm. Investig. 2016, 6, 148-157. [CrossRef]

164. Matanovic, M.R.; Grabnar, P.A.; Voinovich, D.; Golob, S.; Mijovski, M.B.; Grabnar, I. Development and preclinical pharmacokinetics of a novel subcutaneous thermoresponsive system for prolonged delivery of heparin. Int. J. Pharm. 2015, 496, 583-592. [CrossRef]

165. Gritsch, L.; Motta, F.L.; Contessi Negrini, N.; Yahia, L.H.; Farè, S. Crosslinked gelatin hydrogels as carriers for controlled heparin release. Mater. Lett. 2018, 228, 375-378. [CrossRef]

166. Dong, W.; Wang, X.; Liu, C.; Zhang, X.; Zhang, X.; Chen, X.; Kou, Y.; Mao, S. Chitosan based polymer-lipid hybrid nanoparticles for oral delivery of enoxaparin. Int. J. Pharm. 2018, 547, 499-505. [CrossRef]

167. Tang, B.; Qian, Y.; Fang, G. Development of Lipid-Polymer Hybrid Nanoparticles for Improving Oral Absorption of Enoxaparin. Pharmaceutics 2020, 12, 607. [CrossRef]

168. Ramadan, A.; Lagarce, F.; Tessier-Marteau, A.; Thomas, O.; Legras, P.; Macchi, L.; Saulnier, P.; Benoit, J.P. Oral fondaparinux: Use of lipid nanocapsules as nanocarriers and in vivo pharmacokinetic study. Int. J. Nanomed. 2011, 6, 2941-2951. [CrossRef]

169. Eleraky, N.E.; Swarnakar, N.K.; Mohamed, D.F.; Attia, M.A.; Pauletti, G.M. Permeation-Enhancing Nanoparticle Formulation to Enable Oral Absorption of Enoxaparin. AAPS PharmSciTech 2020, 21, 88. [CrossRef]

170. Paliwal, R.; Paliwal, S.R.; Agrawal, G.P.; Vyas, S.P. Biomimetic solid lipid nanoparticles for oral bioavailability enhancement of low molecular weight heparin and its lipid conjugates: In vitro and in vivo evaluation. Mol. Pharm. 2011, 8, 1314-1321. [CrossRef]

171. Abdellatif, A.A.H.; Tawfeek, H.M.; Abdelfattah, A.; El-Saber Batiha, G.; Hetta, H.F. Recent updates in COVID-19 with emphasis on inhalation therapeutics: Nanostructured and targeting systems. J. Drug Deliv. Sci. Technol. 2021, 63, 102435. [CrossRef]

172. Bouazzaoui, A.; Abdellatif, A.A.H.; Al-Allaf, F.A.; Bogari, N.M.; Al-Dehlawi, S.; Qari, S.H. Strategies for Vaccination: Conventional Vaccine Approaches Versus New-Generation Strategies in Combination with Adjuvants. Pharmaceutics 2021, 13, 140. [CrossRef]

173. WHO Issues Emergency Use Listing to Novavax-Serum Institute's COVID-19 Vaccine. Reuters. Available online: https://www. channelnewsasia.com/asia/novavax-serum-institute-covovax-covid19-vaccine-who-emergency-use-listing-2387491 (accessed on 27 November 2021).

174. Henderson, J. What Happened to the Novavax Vaccine? Medpage Today. 2022. Available online: https://www.medpagetoday. com/special-reports/exclusives/96461 (accessed on 27 November 2021).

175. Chung, Y.H.; Beiss, V.; Fiering, S.N.; Steinmetz, N.F. COVID-19 Vaccine Frontrunners and Their Nanotechnology Design. ACS Nano 2020, 14, 12522-12537. [CrossRef]

176. Medhi, R.; Srinoi, P.; Ngo, N.; Tran, H.-V.; Lee, T.R. Nanoparticle-Based Strategies to Combat COVID-19. ACS Appl. Nano Mater. 2020, 3, 8557-8580. [CrossRef]

177. Zimmer, C. Researchers Are Hatching a Low-Cost Coronavirus Vaccine. The New York Times, 5 April 2021; ISSN $0362-4331$.

178. Wadman, M. The long shot. Science 2020, 370, 649-653. [CrossRef] [PubMed] 
179. Wadman, M. Novavax launches pivotal U.S. trial of dark horse COVID-19 vaccine after manufacturing delays. Science 2020. [CrossRef]

180. Wiersinga, W.J.; Rhodes, A.; Cheng, A.C.; Peacock, S.J.; Prescott, H.C. Pathophysiology, Transmission, Diagnosis, and Treatment of Coronavirus Disease 2019 (COVID-19): A Review. JAMA 2020, 324, 782-793. [CrossRef]

181. Baden, L.R.; El Sahly, H.M.; Essink, B.; Kotloff, K.; Frey, S.; Novak, R.; Diemert, D.; Spector, S.A.; Rouphael, N.; Creech, C.B.; et al. Efficacy and Safety of the mRNA-1273 SARS-CoV-2 Vaccine. N. Engl. J. Med. 2021, 384, 403-416. [CrossRef]

182. Polack, F.P.; Thomas, S.J.; Kitchin, N.; Absalon, J.; Gurtman, A.; Lockhart, S.; Perez, J.L.; Perez Marc, G.; Moreira, E.D.; Zerbini, C.; et al. Safety and Efficacy of the BNT162b2 mRNA Covid-19 Vaccine. N. Engl. J. Med. 2020, 383, 2603-2615. [CrossRef]

183. World Health Organization. WHO Coronavirus (COVID-19) Dashboard; WHO: Geneva, Switzerland, 2021.

184. Scully, M.; Singh, D.; Lown, R.; Poles, A.; Solomon, T.; Levi, M.; Goldblatt, D.; Kotoucek, P.; Thomas, W.; Lester, W. Pathologic Antibodies to Platelet Factor 4 after ChAdOx1 nCoV-19 Vaccination. N. Engl. J. Med. 2021, 384, 2202-2211. [CrossRef]

185. Greinacher, A.; Thiele, T.; Warkentin, T.E.; Weisser, K.; Kyrle, P.A.; Eichinger, S. Thrombotic Thrombocytopenia after ChAdOx1 nCov-19 Vaccination. N. Engl. J. Med. 2021, 384, 2092-2101. [CrossRef]

186. Oldenburg, J.; Klamroth, R.; Langer, F.; Albisetti, M.; von Auer, C.; Ay, C.; Korte, W.; Scharf, R.E.; Potzsch, B.; Greinacher, A. Diagnosis and Management of Vaccine-Related Thrombosis following AstraZeneca COVID-19 Vaccination: Guidance Statement from the GTH. Hamostaseologie 2021, 41, 184-189. [CrossRef]

187. Cines, D.B.; Bussel, J.B. SARS-CoV-2 Vaccine-Induced Immune Thrombotic Thrombocytopenia. N. Engl. J. Med. 2021, 384, 2254-2256. [CrossRef]

188. Long, B.; Bridwell, R.; Gottlieb, M. Thrombosis with thrombocytopenia syndrome associated with COVID-19 vaccines. Am. J Emerg. Med. 2021, 49, 58-61. [CrossRef]

189. Oliver, S.E.; Gargano, J.W.; Scobie, H.; Wallace, M.; Hadler, S.C.; Leung, J.; Blain, A.E.; McClung, N.; Campos-Outcalt, D.; Morgan, R.L.; et al. The Advisory Committee on Immunization Practices' Interim Recommendation for Use of Janssen COVID-19 Vaccine-United States, February 2021. MMWR Morb. Mortal. Wkly. Rep. 2021, 70, 329-332. [CrossRef]

190. MacNeil, J.R.; Su, J.R.; Broder, K.R.; Guh, A.Y.; Gargano, J.W.; Wallace, M.; Hadler, S.C.; Scobie, H.M.; Blain, A.E.; Moulia, D Updated recommendations from the advisory committee on immunization practices for use of the Janssen (Johnson \& Johnson) COVID-19 vaccine after reports of thrombosis with thrombocytopenia syndrome among vaccine recipients-United States, April 2021. Morb. Mortal. Wkly. Rep. 2021, 70, 651.

191. D’Agostino, V.; Caranci, F.; Negro, A.; Piscitelli, V.; Tuccillo, B.; Fasano, F.; Sirabella, G.; Marano, I.; Granata, V.; Grassi, R.; et al. A Rare Case of Cerebral Venous Thrombosis and Disseminated Intravascular Coagulation Temporally Associated to the COVID-19 Vaccine Administration. J. Pers. Med. 2021, 11, 285. [CrossRef]

192. Billy, E.; Clarot, F.; Depagne, C.; Korsia-Meffre, S.; Rochoy, M.; Zores, F. Thrombotic events after AstraZeneca vaccine: What if it was related to dysfunctional immune response? Therapie 2021, 76, 367-369. [CrossRef] 